\title{
AN OUTLINE REVIEW OF THE GEOLOGY OF PERU.
}

\author{
[With 5 plates.]
}

By Geokige I. ADAMr.

\section{INTRODUCTION.}

More than a century has elapsed since Humboldt beheld the grand Cordilleras in northern Peru, and more than three-quarters of a century has passed since d'Orbigny studied the section of the Andes in the southern part of the country. Since then many scientists have been attracted to the region and have contributed to the lnowledge of its geology. Their writings are scattered in numerous publications in English, German, French, and Spanish, and no summary of this information has been made. The writer in attempting to learn what is known concerning the subject has gleaned the material which constitutes this paper. The arrangement and presentation of it in the form of an outline review has been undertaken with the hope that it may serve as an introduction to the broader problems with which later geologists may have to deal.

The author's contributions to the geology of Peru have been published in bulletins of the Corps of Engineers of Mines of Peru, and relate principally to the distribution of the Tertiary formations of the coast of which he made a reconnaissance. Later, while engaged in private work, he traveled in the Titicacan region of Peru and Bolivia, crossed the Cordilleras, and entered the forest region of southern Peru, and also saw something of the Cordilleras of the central part of the country. It is not his intention, however, to attempt to incorporate his observations during these journeys to any great extent in this paper, but rather to use them as an aid to the interpretation of the work of others.

The geologic relations of the rocks of Peru have thus far been explained by written descriptions accompanied in some cases by sections, but there are practically no geologic maps. It is to be hoped that the mapping of some type localities may soon be undertaken and that the columnar sections for the various regions may be established and the paleontologic studies correlated with them. The time has arrived when simple geologic reconnaissance can not be expected to yield satisfactory results. 
Accompanying this paper will be found a bibliography of the more important literature, and in the footnotes some additional references are given. Nearly all of the literature of the subject has been consulted in the preparation of this review, but it has not been deemed advisable to publish a more complete bibliography, since some of the articles with elaborate titles have in reality little since some of the quite inaccessible to the general student, can hardly hope to hold place with the more important contributions, hardly hope to hold a essential truths with fewer errors.

\section{Phystcal and Climatic Regions. \\ THI THRE REGIONS OF PERU.}

The dominant physical feature of Peru is the lofty range of the Andes which lies near the Pacific of Peru is the lofty range of the the narrow strip of desert coast and the extensive wooded plains of the Amazon. Accordingly, the country is commonly recognized as ical features and naturally defined regions which differ in their physor "montaña" as it is ; namely, the coast, the sierra, and the forest, inated with the inholled in Peru. The use of these terms origfound their inhabitants, and they have to a considerable extent apt to be misleading. tains. "Selva," meaning fory to a foreigner, since it suggests mounIf terms are selected whing forest, would seem to be more appropriate. South American which may be broadly used in considering the coastal region, thentinent one may appropriately speak of the Pacific region. These terms Andes Mountain region, and the Amazon plains come into use in scientife physiographic signification and should may be learned from the writings. The extension of these regions

$$
\text { pacitric coastal regron. }
$$

$$
\text { Definition. }
$$

The distinction between the coast and the sierra as commonly made coast the agricultural indicated by differences in agriculture. In the tropical climates, while thocts are those of the tropical and subthe temperate zones. These of the sierra are such as are found in abrupt because of the transition from one region to the other is Andes.

With the exception of the part of $\mathrm{P}$. with the approximate western the coast and the sierra corresponds the Pacific slope of the Andes. This is largely determined by elevation and temperature, and is indicated as one travels from town to town by the character of the roofs of the houses of the natives. The writer in drawing the line upon his published maps ${ }^{a}$ used this as a basis for his observations and inquiries in order to obtain reliable information.

Near the Gone of rainfall is deflected slope of the Andes over the coastal plains and to the Pacific Ocean, the division between coast and sierra would be made by continuing the trend of the line into Ecuador, taking co the agriculture, which varies

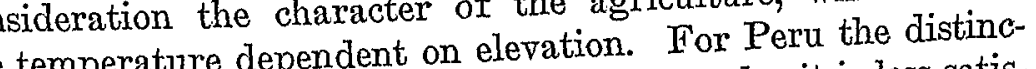
tion based on climate holds fairly well, but in Ecua rainfall the zones factory, since under the Equator and in a region of the topographic of vegetation and agricultion

\section{Divisions of the coastal region.}

The coastal region of Peru may be divided into plains areas and mountainous areas. The plains, according to their geographic posiions in the country, may be called the "northern," "south central," " " (he coast is mounlikewise between the south centron central plains extend inland from tainous. The northern and the southern plains are separated from the shore of the Pacific, but the southern plaininous divisions of the the sea by a coast range of hills. The mountainous dir tributary dry coast are diversified by the stream valleys and their tributary one of valleys and present a very broken topography. The southes abruptly these two mountainous areas, considered as a mass, plateau. The from the sea and presents many aspects of a dissected pline and the northern area is characterized by a more broken coast line sierra. It mountains rise in a ragged, irregular way ther these mountainous would seem to be an open question as to whether thes region. Along areas should be classed with the coast "fothills" rising to the sierra, the inner border of the plains are the "foothills mountainous divisions and at a corresponding distance inland in the mo the "valley heads of of the coast there is a transition zone knowe the valley floors become the coast" (cabezeras de los valles), whe the coast is impossible, narrow and stony, so that the agriculte the temperature and cliand the mountains mate of the sierra. a Maps reproduced in this report as Plates Nos. $2,3,4$ and 5 . 
THE ANDES MOUNTAIN REGTON.

The distinction between the coast and the sierra has alread been explained. [The division lino betwe the slerra has already been region would of the forest sem the presence p. 386 above.) ] implied when the word "montaña" is used. (See part of Peru, The tree line, however, especially in the northern from reading, according to the data which the writer has obtained from reading, rises well up onto the flanks of the Andes, and indeed with the Andes region. forest have ner the limits of the

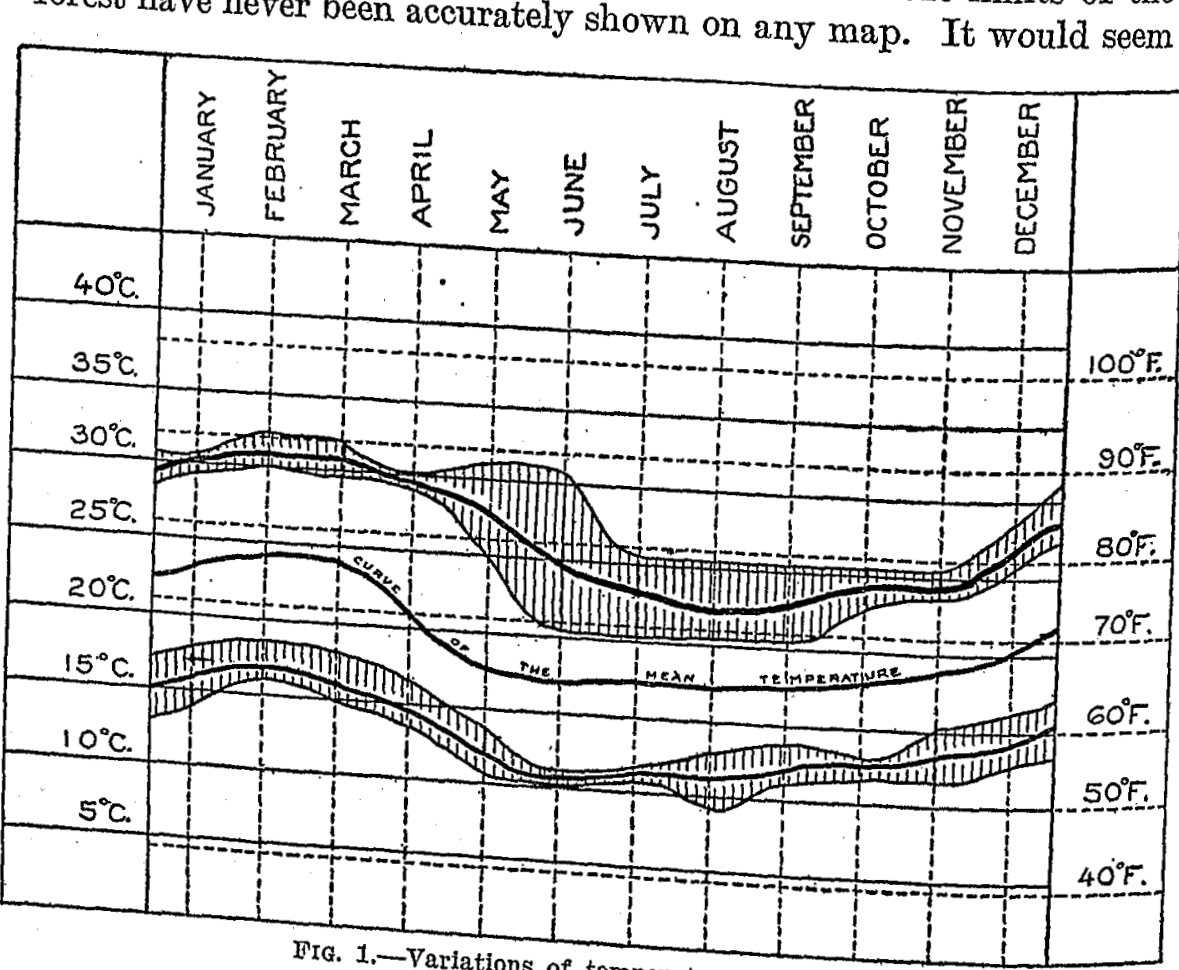

1. - Variations of temperature at Lima.

of the mountains in Amazon region to the plains lying to the east It is not possible to draw this line the division a physiographic one. In the accompanying this line from information now available. hachuring of the mounetch map of the Cordillera of the Andes the possible from available mondi's map of Peru, which is the will be remembered that Raifective, and to a considerable most detailed, is known to be de-

The main features of the Andes region.

$$
\text { ing on it is imaginary. }
$$

will be described in some Andes are the Cordilleras proper, which are the great inter-Andean valleys, which are occupied by streams tributary to the Amazon and which are shown in a general way on which may be named from the rivers occupying them. On the Pacific slope there is one inter-Andean valley between the Cordillera Neora and Blanca known as the "Valley of Huaylas" (Callejon de Huaylas). In addition should be noted the Titicaca Lake basin. If one attempts to go further into the classification of the physiographic features, there are many short ranges of mountains or spurs from the main Cordillera, some of which are named on Raimondi's map, and also high plains and tablelands (frequently called "punas") which are worthy of distinction.

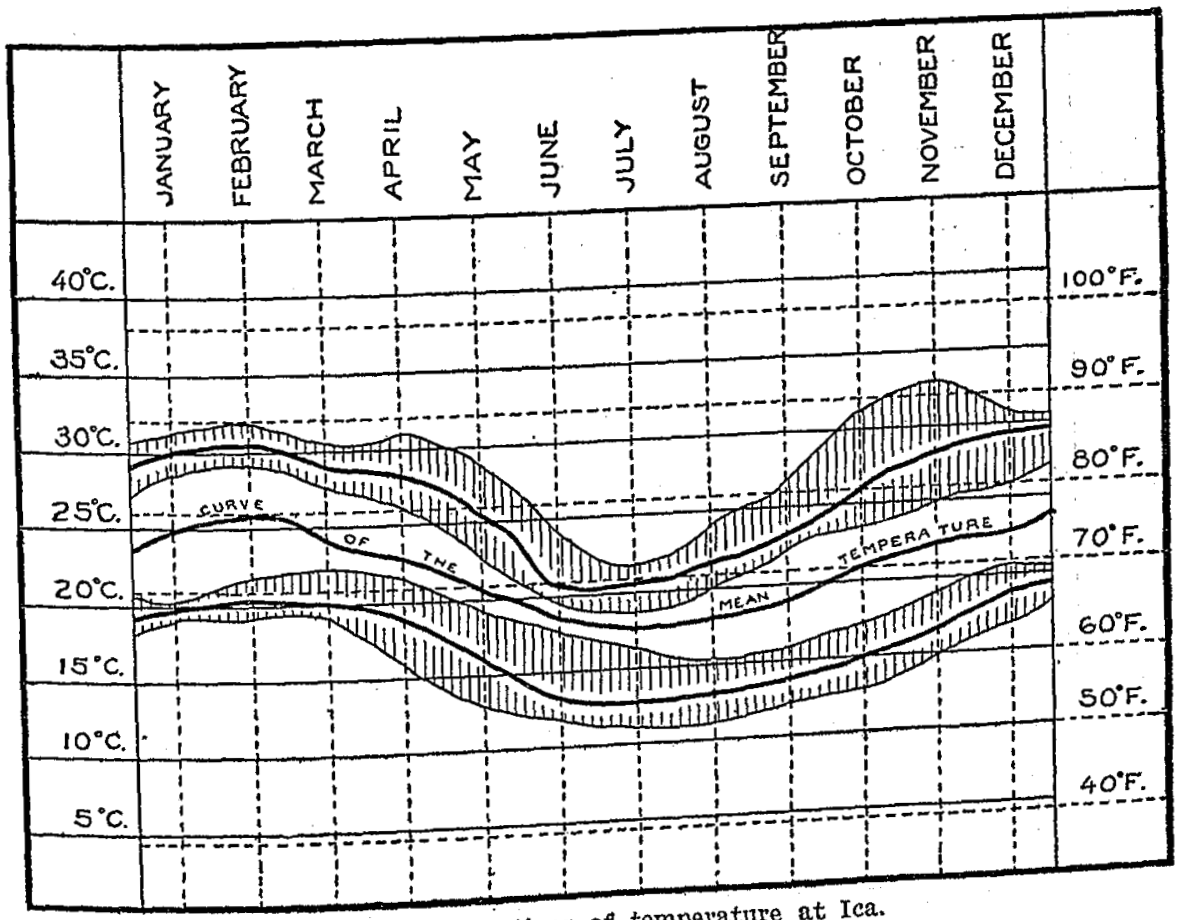

Fra. 2.-Variations of temperature at Ica.

Rainfall in the Andes. The rain which falls in the Andes region is brought as vapor from the Atlantic and most of it is pxordillera which it encounters. Duron the eastern flank of the first Cordlla ing the summer season the clouds rise higher andleras and a part of it west, distributing their moisture on the Cordllerdillera. It is gencrosses the Continental Divide or the weste Pacific slope, the limit of erally believed that the rainfall on the Pacific slope, the limeras, except which has already been discussed, comes over the Cordllerdance with in the region of the Gulf of Guayaquil. This is in al theory of the in thavelers and the gen 
influence of the trade winds. Clouds are not seen passing to the Cordillera from the Pacific. The mists of the coast which drift inland from the Pacific form at the season when the sky in the Cordillera is clear and their movements are with the land and sea breezes. Systematic observations of the rainfall in the Andes region have been carried on at only one locality, namely, Cailloma, which is situated north of Arequipa and just to the east of the Continental Divide.

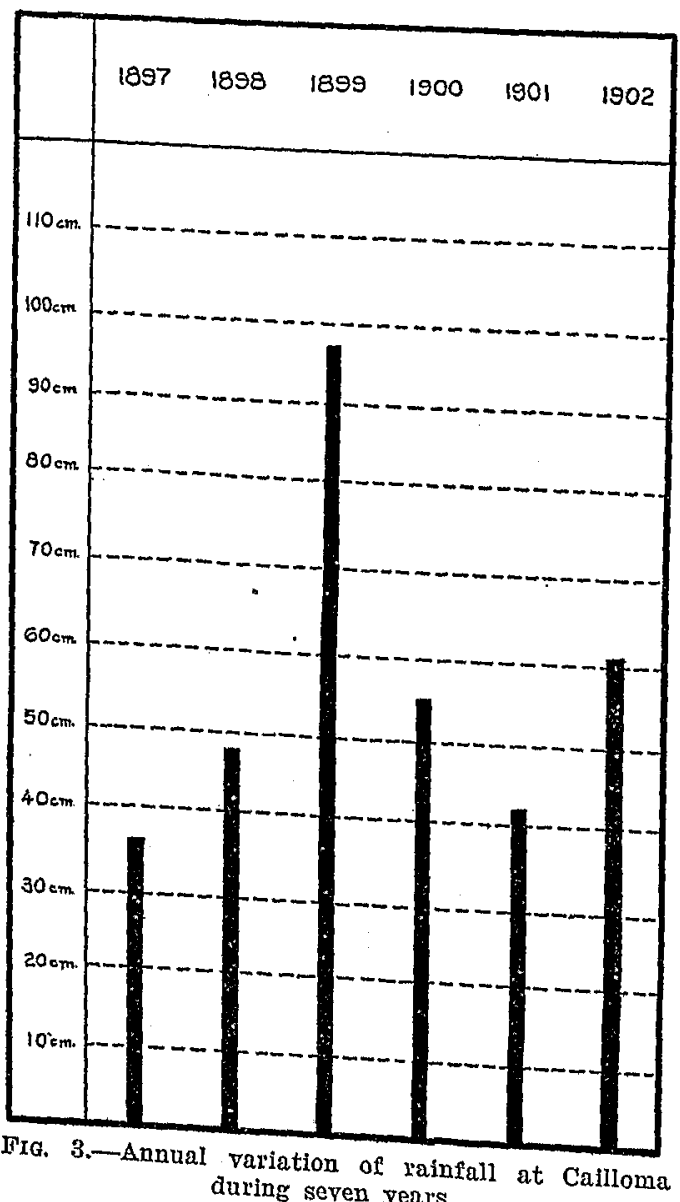

stance, that in southern them the Titicaca basin is a knot which inclu. To the north of the Titicaca basin there and Parinacochas. After this lnota, Carabaya, Abancay, Huando, latitude $14^{\circ} \mathrm{S}$., the Ander this knot of Cuzco and Parinacochas, in ward the two chains lies present a second bifurcation, and north-

From the published data the writer has constructed the accompanying diagrams (figs. 3 and 4) and monthly variations of the rainfall.

\section{The Corditleras of the} Andes.

DESCRTPTION BY HUMBOLDT, 1802.

Although Humboldt did not have Peru as an object of special study did not visit tho country excepting to see coast at Pisco and Lima and to travel in the highlands tween Cajamarca-and the Maranon, " he nevertheless gave a graphic and to a large extent a correct description of the chain of the Andes, availing himself of data furnished by others. He says, in sub-

a Raimondi, El Peru, Volume I, page 15.
The eastern chain extends on the east of Huanta, the convent of Ocopa and Tarma, the western chain passes Castrovereyna, Huancavelica, Huarochari, and Yauli, inclosing a lofty table-land. In latitude $10^{\circ} 11^{\prime}$ the two branches unite in the knot of Huanuco and Pasco (Cerro de Pasco). From this point northward the Andes divide into three chains. The eastern lies between the Huallaga and Pachitea (Ucayali) rivers, the second or central between the. Huallaga and the Maranon, while the third lies between the Maranon and the coast. The eastern range lowers to a range of hills, and is lost in latitude $6^{\circ} 15^{\prime}$ on the west of Lamas. The central, after forming the rapids and cataracts of the Amazon, turns to the northwest and joins the knot of Loja in Ecuar dor. From the most certain information which he obtained he concluded. that to the east of the chain which passes to the east of Lake Titicaca and northward to Huanuco a wide mountainous land is situated, which is not a widening of the easttern chain itself, but rather that it consists

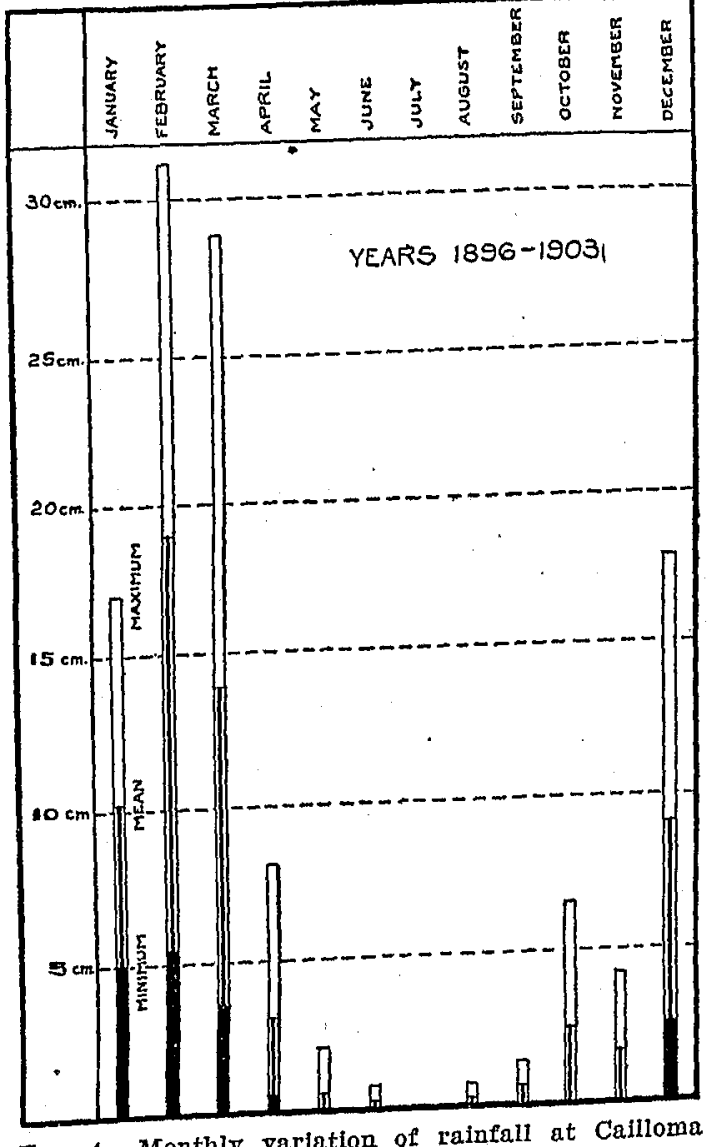
Fra. 4.- Monthly varlation of rainfal of heights which surround the foot of the Andes like a penumbra, filling in the whole space between the Beni and the Pachitea (Ucayali).

Heo direction of the

Humboldt also made interesting comments Andes. He noted that in Chile and Upper Peru (18 $\left.28^{\prime} 35^{\prime \prime} \mathrm{S}.\right)$, the Straits of Magellan to the parallel of Arica (18 in the direction of whole mass of the Andes runs from south to north in thel of Arica the a meridian at the most $5^{\circ} \mathrm{NE}$., but from the paralle alpine lake of coast and the two Cordilleras east and west of the to northwest. Titicaca abruptly change their direction and incline to the 88292-sM 1908- - 26 
In this region, as in general in every considerable widenings of the Cordillera, the grouped summits do not follow the principal axes in uniform and parallel directions, and he remarked that the general disposition of the Andes in this latitude is well worth the attention of geologists. From where the Cordilleras unite in the knot of Cuzco (Vilcanota) their direction is N. $80^{\circ} \mathrm{W}$. He calls attention to the fact that the direction of the coast follows these changes, and remarks that the parallelism between the coast and the Cordilleras of the Andes is a phenomenon the more worthy of attention as it occurs in several parts of the globe where the mountains do not in the same manner form the shore.

\section{DESORIPTION BY RAIMONDI.}

It is to be regretted that Raimondi did not publish a description of the Andes. However, his writings contain much information, and in his edited notes published in the chapter "Apuntes Orograficos," in Volume IV of EI Peru there is a partial description of the Cordilleras. He adopted the nomenclature of Humboldt. The Andes is used as a general term for the whole mountain system, and the various branches are spoken of as "Cordilleras." The branch to the east of Lake Titicaca he called the "Cordillera Oriental" and the one to the west the "Cordillera Occidental." The union of these branches to the north of Lake Titicaca he calls the "Knot of Vilcanota," talking the name from a snow-capped peals. From this knot northward he recognized three branches instead of the two somewhat vaguely described by Humboldt. The Cordillera Occidental follows the direction of the coast. The Cordillera Central separates the valleys of the Apurimac and the Vilcanota or Urubamba rivers, while the Cordillera Oriental separates the interAndean region from the forest region of the interior. These three Cordilleras unite in the Knot of Cerro de Pasco, from which point northward three branches diverge. The Cordillera Occidental for a portion of its way is divided into two, the western of which is known as the "Cordillera Negra" (Black Cordillera) and the eastern or main one takes in that region the name "Cordillera Blanca" (White tral tral separates the Maranon and Huallaga rivers, while the Cordillera The Cordinarates the Huallaga from the Pachitea and Ucayali. at the falls of Central describes a curve, and is cut by the Maranon by the Huall Manseriche. The Cordillera Oriental lowers, and is cut west direction at the Falls of Aguirre and then runs in a northwest direction and joins the Cordillera Central. Humboldt states that in that in the northern part of Peru the description by Raimondi does not differ materially from that by Humboldt. Raimondi gives a description of the Cordillera Occidental and notes a list of 42 of its passes, which vary from 2,186 meters to 5,075 meters. From Huamachuco in latitude $7^{\circ} 45^{\prime}$ southward the 27 passes are more than 4,000 meters above the sea. The lowest pass is that of Huarmaca, in the department of Piura, which is 2,180 meters.

His further description of this Cordillera as to structure, age, and snow line, etc., will be given under other heads in this paper. Here, however, it will be noted that he says the southern part of the Cordillera Occidental is not a single range, but rather a broad elevated band or high plateau, on which are situated volcanic peaks. It may perhaps be added here with propriety that the Continental Divide is a continuous range and that the volcanic peaks do not follow the Cordillera, but are found in an irregular double line crossing the western part of the high plateau. The relation of this line of peaks to the change in direction of the Cordillera is not unlike that of a string to a bow.

It will be remembered that Humboldt spoke of a mountainous area to the east in the forest region. Raimondi did not touch on this point, and indeed it is not yet possible to tell just what is the disposition of the mountains of this region, for although many explorations have been made the wooded country has prevented the mapping of the topographic features. The Cordillera Central, according to Humboldt, joins the Occidental in the lnot of Loja, in Ecuador. Perhaps Raimondi did not ttouch on this point in his description because Loja is outside of Peru, and consequently beyond the limit of his explorations. He seems to have accepted the statements of Humboldt in his mapping.

Wolf, however (1892), in his description of the Andes, says that he in the knot of Loja, as is shown on the map of Ecuador by Santiago Y Morona and of Peru by Raimondi. He states that the Cordillera (5anseriche) is the last cut by the Pongo de Manseriche (Fals of Manses the Amazon. It branch of the Peruvian mountains which reaches the Amazon. It appears not to be very high, since explorers speak of 600 meters at the locality of the falls, and he thinks that to the north it lower

is lost in the plains between the rivers Santiago and Morona.

Wolf also says that to the east of Ecuador from where the are navigable the country is a great plain, with only small areas of gradual undulations, and that the high mountains of the

also those of Raimondi, are imaginary and do not exist.

The accompanying sketch map (pl. 1) shows the disposition of the Cordilleras according to the foregoing descriptic portion is from the sketch published by Wolf. 


\section{THE AMAZON PLAINS REGION.}

It is to be regretted that so little systematized information is available concerning the Amazon region. It has been explored principally along its great waterways, and the forest has prevented travelers from relatively minerensive views of its physical features, which are of insignificant of the compared with the tree-covered area. Most of the sheets of Raimondi's map in the Amazon region are without shores, and Wolf has called attention to the fact that the mountains shown to the east of Ecuador and in a region which Raimondi did rise to the falls fanciful. A chain of hills or an escarpment gives rise to the falls of the Madierra River, but further than this there is bluffs along in the writings of explorers excepting the mention of the region the streams and occasionally hilly areas. Accordingly, to describe or outline the present dismissed without further attempt

\section{Sedimentary Formations.}

CAMBRIAN.

The Cambrian has not been identified in Peru by means of fossils. In some instances in the literature the Cambrian has evidently not bilurian ansidered as a separate era, but has been included in the been discusseding to former usage. Accordingly formations have Cambrian Chanchamayo, which bann (1904) has described green slates near sence of fossils which he says are surely pre-Silurian, but the abtions $a$ having lost het permit of their age being proved. He menwould have thrown light on the Cambrian and Silurian formations.

\section{SILURTAN.}

In his section from southern Peru into Bolivia d'Orbigny (1848) described the Silurian as represented in the Corbigny (1848) where it has associated with it granite, which he stated forms the Forbes (1861) north of Cuzco in Ped the area of the Silurian as extending from and southward to Peru along the Cordillera Oriental into Bolivia features similar to the Silurian a Introduction to parope. He says that it consists Bolivien." of clay slates, shales, and quartzites, but he found no limestones. The fossils which he collected were examined by Salter and showed that probably the whole Silurian is represented. Forbes called attention to the fact that the formation contains quartz veins, and that these have given rise to auriferous gravels. He contradicted the statement of d'Orbigny that the peak Illimani in Bolivia is a granite peak as shown in the section, and says that Illimani and Illampu (Sorata) are composed of slates.

Raimondi (1867) described the Cordillera Occidental as containing slates cut by quartz veins carrying gold, and later (1873) in outlining the geology of the Department of Ancachs he classes the slates as Silurian.

In southern Peru Balta (1897) has classed the slates in the Province of Carabaya and Sandia as Silurian because of the presence of graptolites, and this classification was followed by Pflucker ${ }^{a}$ who, however, contributed little to our knowledge of the Silurian.

Ochoa, in his bulletin ${ }^{b}$ on the Province of Huanuco, in the central part of the Peruvian Andes, makes a brief reference to the finding of graptolites near Huacar, from which fact he concluded that the Silurian is present there.

Steinmann (1904) identified by means of graptolites the lower Silurian in the region of Tarma, also in the central region of the Perunith associated with the Silurian indes, and he oriental made its appearance in lower Silurian time.

Farther to The the north Raimondince of Huari, near Department of Ancachs, states that in are older sediments with 列 a great formation of talcose slat not mention any fossils. He also to the Silurian, although he did not mention any foss of Cordilstates that there is a similar area on the western slope of the Cond in lera Nevada (Occidental) at Pallasca. Farther to the nor the divide the foothills of the Cordillera Occidental, in passing over the writer saw from Motupe to Olmos and in the vicinity of Olmos, the wrin sand extensive exposures of slates cut by numerous quan is here made stringers which have been prospected for gold. Murian, but it should of the area because of its resemblance to the siluniand.

not be definitely classed until fossils have been the paleontology of A paper which has an important bearing (1892) describing an exthe Silurian was published by A. Ulrich (1892) de cuerpo de

a Informe sobre los yacimentos auriferous de Sandia,

Ingenieros de Minas del Peru No. 26, 1905, Luis Pflucker.

$b$.

${ }^{6}$ Recursos minerales de la provincla de Honor G. Ochoa
genieros de Minas del Peru No. 9, 1904, Nicanor 
tensive collection of fossils from the Silurian and Devonian of Bolivia made by Steinmann. Inasmuch as the same faunas probably extend into Peru the descriptions of the fossils will be of value when similar studies are undertaken farther northward. Recently Dereims (1906) has described the occurrence of the Silurian at many places in Bolivia, some of which are near the border of Peru in the Titicaca basin, although most of them are to the south in the Cordillera Real (Oriental) of Bolivia, but he has not yet described his collections of fossils.

\section{DEVONIAN.}

The first recognition of a Devonian locality which has a bearing on the geology of Peru was by d'Orbigny (1842), who made collections in the Titicaca Lake region in Bolivia and found fossils which he described as characteristic of that period.

Forbes (1861) when in the field did not distinguish the Devonian, included it with the upper Silurian. Later he was induced by Salter, who studied the collections of fossils, to show the Devonian admitted to because of the finding of Phacops latifrons, which is Bolivia to be a truly Devonian species. Forbes's localities are in Take Titicaca.

Mention has already been made of the collections from Bolivia made by Steinmann which were studied by A. Ulrich (1892) and found to contain an interesting series of Silurian and Devonian fossils. The descriptions by Ulrich will be of value when the Devonian in adjacent parts of Peru receives critical study.

Devonian in Dereims (1906) has described the occurrence of the stones of differentia, near Lake Titicaca. He says it consists of sandless importanerent colors and thiclnesses, alternating with shales of he mentions, but he obtained a collection of fossils, some of which All the foreging hat yet published his paleontologic studies. bearing on the geoliterature pertains to Bolivia, but it has a direct tends across theology of Peru, since the Devonian undoubtedly exfossils have been describe the Titicaca basin. Thus far no Devonian fossils from has reported to be Devonian specifically.

CARBONTFEROUS.

The Carboniferous in Bolivia was studied by d'Orbigny (1848), who described a number of fossils. This was the first information which gave a definite reason to suppose that the Carboniferous exists

a Enrique I. Dueñas. Bol. del Cuerpo de Ingenieros de Minas del Peru No. 53 in Peru, since the localities are very near the border. D'Orbigny also referred the rocks at Arica to the Carboniferous on very slight evidence, but this has been refuted by Forbes. The writer ${ }^{a}$ found fossils at Arica, which, according to Bravo, are Cretaceous, although he did not determine them specifically.

The Carboniferous areas examined by Forbes (1861) are on the peninsula of Copacabana and the projecting headland opposite on Lake Titicaca. On account of a declaration of war Forbes was placed in a suspicious position, since these localities are on the frontier between Peru and Bolivia. He, however, obtained a collection of fossils which were determined by Salter. Forbes states that the Carboniferous is also to be found to the north of Lake Titicaca.

The fossils collected by Agassiz (1876), together with some others, were studied by Derby (1876), who described 9 Carboniferous speine from Yampata and the island of Titicaca. He also found a Spirifer in materials brought by James Orton from the Pichis River, Spirifer in materials brought rhynchus from near Mayobamba in northern Peru. Agassiz, in the rhynchus from near Mayolom notes accompanying Derby's paper, states that specimens of Tusulina were sent to Mr. Brady for identification. The notes as to the occurrence of the Carboniferous are by Agassiz, who says that near Lake Titicaca it lies in a rather limited elongated basin, with the axis in a Titicaca it lies in a rather limited elongarified the Carboniferous at northwest-southeast direction. He identified the Carboniferous at Vilca, Santa Lucia, and Sumbay, and says that Mr. Orrego stated that Carboniferous is found as far north as Caylloma, and quotes Orton as saying that Raimondi reported he had traced the Carboniferous series to a height of 1,400 feet on the Apurimac at a locality intermediate between the Pichis River and Cuzco. It would seem to the identification of the Carboniferous at the places mentioned by Agassiz, and especially those reported by $\mathrm{Mr}$. Orrego, should not be definitely referred to the Carboniferous. The writer in journeying to Caylloma observed sedimentary formations which appear to be Cretaceous.

Bullished shetch in the locality from shown to exist, namely, in the Titicaca basin and the lo added nothwhich Orton's Carboniferous fossils were obtained. He added noth ing especially new.

A small Carboniferous area was reported ${ }^{0}$ by Fuchs (1900) as in being found in the peninsula of Paracas jus Pacific coast. The formation there contains some thin coal which a See Boletin del Cuerpo de Ingenieros de Minas del Peru, Paracas, Tr. O. Fuchs, ${ }^{b}$ Nota sobre el Terreno Carb 
an attempt is being made to exploit. With the coal, fossil plants were found by Fuchs. This is an important addition to our knowledge of the distribution of the Carboniferous because of the geographic position of the area.

Steinmann (1904) reported the finding of a few characteristic Carboniferous fossils southeast of Tarnia.

The Carboniferous in Bolivia, especially in the region of Lake Titicaca, was studied by. Dereims (1906), who describes the formation as composed of sandstones and shales, with a bed of dark limestone at the base and with coal beds. He investigated the coal four leagues north of Mocomoco, at Ococoya and Calacala, where it does not exceed 80 centimeters and consists largely of shale impregnated with carbonaceous matter and is not workable. In the peninsula of Copocabaña, near Ýamupata, he saw thin beds of coal, which have formerly been worked, but the coal is mixed with shale and contains so much sulphur that it can not be used. He states that on the island of Titicaca it is of the same general character. His conclusion in regard to the Carboniferous in Bolivia is that it is the lower or Dimantian stage, and is everywhere marine and contains no workable
or good coal.

\section{PERMIAN.}

The Permian is not known to be present in Peruvian territory. Certain sandstones in Bolivia which extend into southern Peru in the Titicaca region were early classed as Permian or Triassic by forbes because of their resemblance to the typical Permian of Russia described by Murchison. Forbes, however, states that no fossils having been found, the age of the beds is a question for inquiry. The celebrated minains salt and gypsum beds and native copper, the lebrated mines of Cora-Cora being found in them.

Steinmann (1906) has discussed the Cora-Cora copper deposits and are found. He says that sandstone to the formation in which they rine sediments in Bolivia the formation comprises the youngest mameters. By the findinia and has a thickness of more than 1,000 in related formations a fossils near Potosi, in southern Bolivia, ${ }^{a}$ ingly he assigns them to ther age than Jura is indicated, and accord-

Dereims (1906) says that at Santa Lucia, near Potosi, he found that are calcareous and reddish gypsiferous shales with some beds full of Chemnitzia which are of Permian age. The calcareous bed is marks that d'Orbiony potosensis, first described by d'Orbigny. He relithologic grounds, but has referred this formation to the Trias on a comp fossils it appears that it is Permian${ }^{a}$ Compare Steinmann, Hoek, and V. Bistraus. Zentralblatt für Mineralogie
etc., 1904, p. 3, zur Geologie des sudostichen Boliviens.
Carboniferous or Permian. It will be remembered that d'Orbigny described Chemnitzia potosensis from the Triassic, but the diagnostic value of the genus for indicating the Carboniferous or Permian may well be questioned, since the genus is also found in the Mesozoic. Moreover, it will be recalled that the evidence by Steinmann just cited is opposed to the conclusions of Dereims.

TRIASSIC.

D'Orbiony (1842) referred to the Triassic a series of variegated D mentions only one, Chemnitzia potosensis, the others having been lost The age of these beds seems to still be in doubt, Dereims having referred them (1906) to the permo-Carboniferous as has already been mentioned.

Iater Forbes (1861) commented on the classification by d'Orbigny and states that it would appear that d'Orbigny proceeded on the supposition that no link in the geologic chain should be deficient. Forbes classed these rocks as Permian or Jurassic, but stated that their age is a question requiring more study.

Raimondi (1873) in his volume on the Department of Ancachs (and salt and gypsum. This seems to have been done in accordance with the general relations of the rocks and to make the geologic succession complete. It will be remembered that the fossils sent by Raimondi to Gabb were not given close diagnostic values, and so the classification by Raimondi has really little value. In several places. Raimondi spealss of the Triassic as being present, but unfortunately little reliance can be placed on this. According to Steinmann's later writings (1904) the red sandstones and shales with salt and gypsum beds are to be classed as Cretaceous (Lower Liassic). ${ }^{a}$

\section{JURASSTO.}

D'Orbigny (1842) found no fossils- of Jurassic age and did not fiscussed the probcolor any part of his section as Jum America.

abilities of its being present in South Am the east slope of the Cor-

Crosnier (1852), in his explorations on the east slope of the Cy $\mathbf{M}$. dillera Occidental, found some fossils which we Arca gabnelis of the Bayle as Jurassic. He mentions an Arca like Ara gas likewise deNeocomian. Also an Ammonite from near Oroya was lykem termined as Jurassic.

For Jurassic or Permian a series consisting principall of a Bol. No. 12, p. 24. 
rocks were classed by d'Orbigny as Devonian and Carboniferous and in part Triassic, but he cited no fossils. Forbes says that the beds contain plant remains (coniferous indeterminable) and he was informed that a complete Saurian head had been extracted from the beds by $M$. Ramon Due, but was not successful in obtaining it nor some fossil bones and teeth now in the Museum of Avignon in France, sent there by M. Granier of La Paz. The character of these beds, as already stated in describing the Permian, is like the typical Permian of Russia. Forbes concluded that their age must await the finding of fossils.

Raimondi (1873), in his study of the Department of Ancachs, classes as Jurassic certain formations containing coal and yielding ammonite fossils. However, he had no other determination for his fossils than that furnished by Gabb, which was not very critical and so we must rely on later work for the differentiation of the Jurassic. It will be seen later that the plants and invertebrates from the coal horizon of the Cordillera Occidental have been shown to be Cretaceous. However, Raimondi in some instances was probably correct in assigning formations to the Jurassic, since it is now lnown to be present and has yielded numerous fossils. Bravo has called attention to the fact that Gottsche ${ }^{a}$ has made mention of an ammonite from Morococha which is in the Freiburg collections.

Fossil ammonites from Huallanca, in the Department of Ancachs, studied by Durfeldt and belonging to the Freiburg Museum, were studied by Steinmann (1881) and considered by him as indicating ing in the (which is homotaxial with the Portlandian) and belonging in the upper part of the Jurassic.

\section{CRETACEOUS.}

The island of San Lorenzo at Callao was examined by Dana, and his description is published in the report of the Willes expedition (1849). He made some detailed sections of the rocks and found in a footnote to he considered as indicating the oolitic. He refers some fossils to the fact that James Delafield had reported ${ }^{b}$ upon and presented to Doctor Brinkerhoff had collected from the island field did not Doctor Pickering, an opinion as to the age of the fossils.

head of the Chering, who was with Dana, found an ammonite at the similar to Chancay Valley at an elevation of 15,000 feet in rocks in the appendix of Lorenzo Island. This specimen is described sils from Trujillo are also figured.

Carl Gottsche, Cassel, versteinerungen aus der Argentinische Cordillere. Dr.

Amer. Journ. Sci., Vol. 38, p. 201, 1839.
D'Orbigny discussed the occurrence of the Cretaceous in South America, and in his section shows an extension of porphyritic rocks on the west slope of the Cordillera Occidental; he did not differentiate the Cretaceous, but evidently included them with the porphyries with which they are interbedded.

In the section which Forbes made from Arica to Bolivia he classified (1861) as oolitic (Liassic) the rocks at Arica, which he describes as shales, claystones, and embedded porphyries, and stated as his reason for doing so that to the south of the district which he studied the rocks are abundantly fossiliferous and had yielded to the researches of Bayle and Coquand and Phillipi about 35 species of recognized oolitic forms. On his map he showed a considerable extent of oolitic in the Cordillera Occidental of southern Peru.

Apparently, Raimondi attempted to identify the fossils which he collected, although he did not describe them. He evidently used the fossils as a guide in determining as best he could the age of the sedimentary formation, which he discusses in his various writings. When he sent his collections to Gabb to be described he accompanied them by a letter (1867) in which he outlined the geographical distribution of the sedimentary formations of Peru. According to his idea, Cretaceous (with Jurassic, Lias, and Trias) is distributed principally in the western Cordillera. He thought the stratified rocks near the Port of Ancon, at San Lorenzo, near Callao, and at Chorillos, to be Jurassic or Liassic. These localities have since proven to be Cretaceous, as will soon appear in this paper. Unfortunately, Gabb's determination of the Mesozoic fossils was delayed and, moreover, he did not give to them such diagnostic value as would help Raimondi to revise his ideas in his later writings.

In his idus in (1873) as Cretaceous certain limestones with echinoderms, oysters, and other fossils. This seems to be correct as viewed in connection with the determination of the Cretaceous in other localities, where it consists largely of limestone and contains similar fossils.

In his geological sketches (1876) Agassiz states that Mr. William his return from the River Purus, presented him Chandless, upon his return from interest and undoubtedly belongwith fossil remains of the highest interest and undoubtedly dquiry, ing to the Cretaceous. They were collected on the Rivies varying latitude $10^{\circ}-11^{\circ}$ south, longitude $67^{\circ}-69^{\circ}$ west, in localtial, remains from 430 to 650 feet above sea level. Among the material, remains of a Morosaurus and of fishes were found. Chandless ${ }^{a}$ says that thed material identified by Agassiz consisted of two perfectly prosed thus vertebræ of Morosaurus. These are the only vertebrate remains thus

$a$ " Notes on the River Aquiry, the principal affuent of the Purus," William Chandless, Journal Royal Geogr. Soc., Vol. 36, p. 119. 
far mentioned as from the Cretaceous of Peru. It may not be improper to recall, in this connection, that Forbes in discussing the Permian or Triassic of Bolivia says that he was informed that a complete Saurian head had been extracted from the beds and also some fossil bones and teeth. This material appears never to have been studied critically and not even a generic name has been applied.

The Mesozoic fossils sent to Gabb by Raimondi were described (1877) and figured, but since then they have not been reviewed critically and studied in connection with further collections, excepting that the descriptions have been referred to by later workers. The opinions which Gabb ventured to give were not very definite, as would naturally be the case in dealing with meager and scattered collections, In several instances he simply stated the age of the beds according to the opinion of Raimondi. Gabb gave with his paper a synopsis of the South American invertebrate paleontology and a bibliography of South American paleontology.

A number of fossils collected by Durfeldt from the coal-bearing formation at Pariatambo, Peru, and belonging to the Freiburg indicating were studied by Steinmann (1881) and determined as indicating the Albien and marine origin of the beds.

This was the first paper by Steinmann dealing critically with the paleontology of Peru. To him and his colaborers we are indebted for a number of subsequent papers which are published under his South America Contributions to the Geology and Paleontology of

The material from Peru studied by Gerhardt (1897) consisted of a block containing fossils from Morococha (Pariatambo), sent by Don Jose Barranca, of Lima, to Doctor Steinmann. By dissolving the stone in acid a small fauna was obtained. The additional fossils from the Strasburg Museum were those collected by Reiss and Stubel from the same place. With this material he was better able to determine the age of the beds which Gabb had considered as Liassic and Steinmann had determined as Albien on the border between beds of Paritater Cretaceous. He concludes that the coal-bearing beds of Pariatambo are of marine origin, and that certainly in Albien and north A frica. Iana reigned which was related to that of Europe Ammonites Andii In studying the fossils of Venezuela he identified so concluded that Gabb from Peru with a Venezuela Lenticras, and

The paleontological lower Senon was present in Peru.

Paulcke (1903) in so paper on the Cretaceous of South America, by fauna studied , in so far as it pertains to Peru, is a filling out of the Cretaceous. Most of the and extends our lznowledge of the upper Stubel in Cajamarca specimens were collected by Reiss and were collected by J. Bamberby places in northern Peru, but some upper Cretaceous represented. He says, in summing up concerning the lower Cretaceous, that in Peru the only highest part of the lower Cretaceous (the Albien) is certainly known and the Neocomian probably may be present.

In various bulletins ${ }^{a}$ of the Corps of Engineers of Mines of Peru J. J. Bravo has published (1904-1906) determinations of Cretaceous fossils and has described some species. This is the most important work done in paleontology by a Peruvian. Through his efforts the corps is gradually acquiring a collection of fossils and developing a paleontologic literature. Bravo has called attention to the fact that previously Pflucker y Rico had collected fossils and given a relation ${ }^{b}$ of localities and a list of fossils obtained in the districts of Yauli (Morococha), but the collections were lost. He also cites two species of Pseudo-ceratites from Yauli, described by Hyatt. ${ }^{\circ}$

In 1904 Habich, in his report on the coal deposits of Checras, in the Province of Chancay, ${ }^{2}$ mentions the finding of Cretaceous fossils in limestones and plants in the coal-bearing beds.

Similarly Malaga Santolalla (1904) found fossils in Hualgayoc ${ }^{\circ}$ and concluded that the middle or upper part of the Cretaceous is represented there. He also gives $f$ a list of fossils from the Province of Cajamarca described by various authors.

In his report on the Province of Colendin ${ }^{g}$ he likewise gives a list of Cretaceous fossils. Lisson (1905) collected a few fossils from near Chollos, just south of Iima, and described ${ }^{\text {" }}$ some Annelid tubes, and a new species Sonnerata Pfluckeri and redescribes S. Raimondianus Gabb.

In the winter of 1903-4 Steinmann made some collections in the The the San Lorenzo in front of Callao. This material was studied by Neumann, who also included Cossils in the Hamburg Museum, from Lucha, and the quebrada of ans the Cretaceous was very incompletely says that up to this time the Cremledge no lower Cretaceous had lnown and that according to his knowledge no lower Cretaceu Neubeen found. The fossil plants from San Lorenzo, studied by Nou

$a$ Bulletins Nos. 10, 19, 21, 25, 35, 51, dealing with the Provinces of Cajatambo, Cajabamba, Pataz, the district of Morococha, the Prort

cayo, and the Province of Huamachuco, respectively.

${ }^{b}$ Apuntes sobre el distrito minera

Minas deI Peru, Tome III, 1883.

c Pseudo-ceratites of the Cretaceous, U. S. Geol. Su, 1. A. V. de Habich.

Bol. de Ouerp

$f$ Bol. No. 31

gol. No. 32.

File algunos Sonneratia de

$n$ Bol. No. 17, Los Tigillites

Morro Solar. Carlos I. Lisson. 
mann, were found to be Neocomian (Wealdan) flora. The fauna from San Lorenzo was also referred to the Neocomian. The faun from Huallauca, Lucha, and Chaco was found to be Albien, with the Rotomagien (?) lower Cenomian also represented at Huallauca. The Santonien was determined at Abra de Charata (between Oroya and Tarma), and from Lucha and Huallauca and Le Quinua. The rich material described increased the number of Senonian fossils from Peru and contained some entirely new forms, while the Wealdan flora was the first found in South America.

It will be remembered that Steinmann (1906) has referred to the Cretaceous the Puca sandstone formation, so named by him and which includes the Cora-Cora copper mines of Bolivia. This has already been discussed under the heading of the Permian. The Puca sandstone extends into Peru.

\section{TERTIARY.}

\section{Marine Tertiary of the Pacific coast.}

The marine Tertiary of the southern coastal plains was described by Forbes (1860), who called it the "Tertiary and diluvial formation d'Orbigny (1842) formation is also shown in the section by d'Orbigny (1842) and by Pissis (1856), who, however, did not devote much attention to it. According to Forbes the Tertiary extends inland from the stretch of low coast lying to the north of Arica, forming gently sloping plains which show evidence of ancient sea beaches. The plains are composed of sand, earth, and gravel, with abundant fragments of porphyritic rocks from the mountains to the east. Forbes mentions a trachytic volcanic formation seemingly condeposited while they plains formation, which appears to have been is in the form they were still under water. This volcanic material by other deposits.

In discusaing th

in territory that now saline deposits of the coastal plains (especially the exception of now is in Chile) Forbes advances the idea that with is due to volcanic causes all evaporating can callines are such as would be left by left. This lacustrine or by mutual reactions of saline matters thus and states that the hypothesis he applies to the nitrate deposits elevation have inclosed a hills to the west is such as might on with the the factor of rainfall and deposits at high elevations he includes the lagoon type as the low states that they are not so characteristic of

The next reference lower deposits near the coast. formations in the northern coastal plains. Among the fossils sent by Raimondi to Gabb there was a collection from Payta. Gabb, in addition to describing them (1869), states that one set of four or five specimens was made up of extinct forms, while the remainder appeared to be Pliocene.

Orton (1870) mentions some fossil shells of living species which he collected from the bluff at Payta and which were determined by Gabb.

The portion of the Tertiary formations of the northern coastal plain lying between Payta and the Ecuadorian frontier was explored and described by Grzybowski (1899). He traveled from Payta to Talara, thence to Tumbez, and up the Tumbez River to Casadero, from which place he returned to the coast. He made the following divisions of the Tertiary:

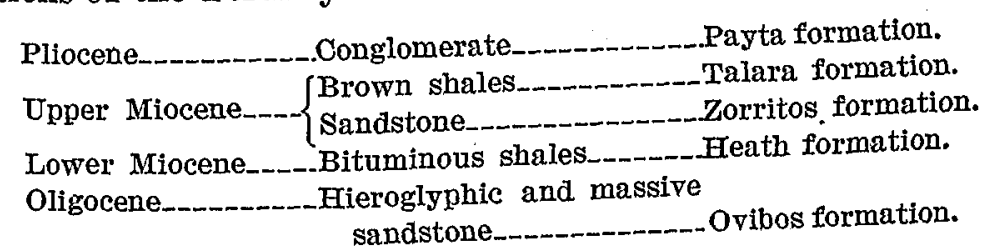

He collected and described fossils from these formations. The Oligocene, however, he distinguished more from stratigraphic relain accompanied by a sketch map and slretch sections showing the localities where the formations were found. River, and called certain rocks in the region of Casadero Paleozoic but did not identify them by means of fossils. He regarded the Paleozoic as pushed up through the broken Tertiary. At Payta he noted a shale formation (no fossils) on which the Tertiary rests.

\section{Lacustrine Tertiary of the Sierra.}

In the Bolivian Plateau d'Orbigny (1842) described an ancient alluvial and pampean formation, the relations of which are shown acts (1856) also showed in the section accompanying his report. Pissis (18) volcanic tuff in this formation but with an interbedded stratum of volcanic tuff the Titicaca basin region.

Teposits under the name "De(1) varies from place to luvial of the Interior" and explained that it derived. In his section place according to the rocks from which it is derived. Tn that it seen he shows locally a bed of trachytic

in the valley of La Paz, in Bolivia.

Agassiz (1876), in the paper accompanying his Titicaca basin sketch of Lake Titicaca, noted the lake deposits in the Thove the present and said that there are terraces up to $300-400$ feet ats former extenlevel of the lake, and made some comments as to its forn 
sion when at that stage. The most definite of these comments is, that in the direction of Pucara (to the northwest) the lake reached to Sta. Rosa. He also remarked that Tiahuauaco, which is a ruin of a temple older than the Inca civilization, is 75 feet above the present level of the lake. From this we may judge that since the Indo-humanic period, as recorded by the oldest monuments in the region, the lake has not fallen more than 75 feet.

In journeying to the departments of Huaucavelica and Ayacucho, Crosnier passed through the valley of Jauja, where he found a formation which he considered (1852) to have been formed in an interAndean lake about 30 miles long and from 9 to 12 miles wide. The deposits are described as consisting of clays and gravels such as would have been transported by streams. He estimated the thickness at from 600 to 700 feet (200 to 300 meters). In the basin of Ayacucho he also found a Tertiary deposit consisting of marls and tuffs. No proof as to the age of these beds was given, but they were classed as Tertiary from their general relations.

In his bulletin on the Mineral Resources of the Provinces of Jauja and Huancayo, ${ }^{a}$ Dueñas (1906) says that the valley of Jauja was in former times the bottom of a great lake, which, by cutting the canyon which is its natural outlet, has gone dry. The lake deposits he considered to be of glaco-fluvial origin. He published two photographs of river terraces cut in these deposits. Dueñas does not refer to the description of the lacustrine formation by Crosnier, with which he no doubt was familiar. The action of glaciers in connection with fluvial action bringsin a new factor to explain the origin of the beds. The author has seen a portion of the Jauja Valley, and is inclined to doubt that glaciers contributed directly to form the deposits, although products of glacial action were undoubtedly brought in by rivers. If, however, lake beds were all deposited during the glacial period we must refer them to the Pleistocene of the Quaternary and not to the Tertiary, as was done by Crosnier. This is a matter for

To the northwest of the Titicaca Basin, Dueñas (1907) observed certain deposits in the Department of Cuzco, ${ }^{b}$ which he says are probably of lacustrine origin. They occur at several localities, differing considerably in character. He mentions beds of tuffs and a stratum of tripoli, in which he reported finding sponge spicules. Because of finding these spicules he says that one might be induced to suppose that in Tertiary times southern Peru was under the Pacific Ocean. This is an unfortunate remark, since it is liable to be perpetuated in the literature by being quoted without questioning whether spicules

a Bol. del Cuerpo de Ing. de Minas No. 35.

Minas del Peru of marine sponges are actually present in the deposits. Although Dueñas finally accepts the lacustrine theory for the deposits, he goes rather far when he remarks that it is nothing wonderful to suppose that Lake Titicaca once extended into the Department of Cuzco. From what the writer has seen of the topography it appears altogether improbable; and, moreover, the theory of local lakes would account in a more satisfactory manner for the occurrence of the formations.

$$
\text { Tertiary of the Amazon region. }
$$

James Orton, in his explorations of the upper Amazon Valley, collected some shells from Pebas, which he submitted to Gabb, who determined them (1868) as late Tertiary. Because of the finding of these shells, Orton refuted the theory of the glacial origin of the clays of the Amazon basin presented by Agassiz and discussed later in this report. Orton (1870) gives a description of the exposures along his route of travel. He says that along the Napo River the only spot where the rocks are exposed is near Napo village, where there is a bed of dark slate dipping east. Farther west, at the foot of the Ecuadorian Andes, the prevailing rock was found by him to be mica schist. The entire Napo country is covered with an alluvial bed on an average 10 feet thick. The formation of the bluff near Pebas he described as consisting of fine laminated clays of many colors, resting on a bed of lignite or bituminous shale and a coarse iron-cemented conglomerate.

After Gabb described the collection of shells from Pebas, a larger collection was made by Mr. Hauxwell, a part from Pebas but most of them from 30 miles below Pebas, at Pichua. Among them Conrad found (1870) seven species of Pachydon (Gabb), a genus which does not have any living representative and is very different from any existing fresh-water genus. He says that it is not possible to state without doubt what the relative stratigraphic position of the group may be, but if all the species are extinct it can not be later than Tertiary, and that it may have lived in fresh or brackish water, but it is certainly not of marine origin.

A collection examined by Conrad (1874), who questioned there being evidence of the marine origin of the shells.

\section{QUATERTARY.}

\section{Pleistocene glaciation.}

Ocourrenoe of Show Peaks.

Humboldt, in his personal narrative (1814), called attention to the absence of snow peaks between the Nevada Huaylillas in latitude $7^{\circ} 55^{\prime}$ and Chimborazo in Ecuador.

$$
88292-\text { SM } 1908-27
$$


Raimondi (1873), in speaking of the Cordillera Occidental, says that snow peaks are numerous in southern Peru, but that the most colossal and gigantic are those in the portion known as the Cordillera Blanca, in the Department of Ancachs. Cerro Hundoy, in front of Caraz, is 6,828 meters high, while the bicuspate mountain Huascan, which dominates Yungay, rises to an elevation of 6,668 meters in its northern peak and 6,721 meters in its southern peak. This is near the northern termination of the perpetual snow. He also states that Huaylillas is the most northern snow peak in Peru.

In the Cordillera Central and likewise in the Oriental there are snow peaks which are mentioned by many writers, but thus far no special study of the distribution of the perpetual snow has been made.

Tae Lower litmit of Perpetuan Snow.

Pentland (1830) made numerous observations as to the occurrence and lower limit of perpetual snow in southern Peru and in territory which is now in Bolivia. He placed the limit at 17,061 feet, and arrived at the conclusion that it is higher than would naturally be expected and especially when compared with pealss nearer the Equator. He attempted to explain this anomaly as due to aridity and excessive evaporation. Raimondi (1879) has given 14,700 feet as the average of the lowest limits in the Department of Ancachs. In the Cordilleras, in the southern part of Peru, he places the limit at 15,100 feet or more. He commented on the previous observations and explained that there seems to be a considerable error in Pentland's determinations of altitudes and considers the deductions from them as erroneous. Raimondi gives the following table of the generally admitted elevation of the lower limits of perpetual snow:

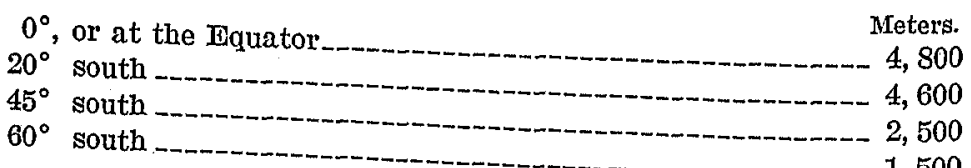

Gladtation.

After examining the evidences of glaciation in Bolivia and southern Peru, Hauthal ${ }^{a}$ (1906) in a short notice gave as his opinion that the glacial period similar to those of the present prevailed during gave rise to glaciers that a lower temperature, due to cosmic causes, eral glaciation.

Duñas $(1007)$,

the glaciated (1907), in his report on the Department of Cuzco, examined a glaciated mass of igneous rock known as the "Rodadero" on the a Quartare vergletscherung der Anden in Bolivien und Peru, Zeitschrift fiur.
gletscherkunde, Band I, Heft 3, September, 1906, p. 203, hill above the town of Cuzco, and expressed his opinion that the whole valley in which Cuzco lies was occupied by a glacier. The evidence given for so great a glacier is not quite so complete as might be wished, at least its lowest limit should be determined. According to Dueñas the elevation of the Rodadero is 3,900 meters; the present limit of perpetual snow in that region is at 4,300 meters, and Cuzco is at 3,450 meters.

Undoubtedly the limit of perpetual snow was much lower during the glacial period. Just how much lower, is a question deserving of study. Raimondi has noted (1873) the occurrence of moraines much below the present snow line in the Cordillera Blanca.

At many places near the snow fields abandoned cirques may be seen below the limits of the perpetual snow and the diminutive glaciers of the present time. The writer has studied the glacier beds and moraines in the vicinity of Poto to the north of Lake Titicaca in the Cordillera Oriental and has estimated that in the glacial period the ice fields extended about 2,500 feet lower than the present glaciers. ${ }^{\oplus}$

\section{Recent elevation of the coast.}

OBervations at SAN LoRenzo IsLaNd by Darwin.

In 1835 Darwin visited Peru and landed at Callao, but because of the troubled political condition he saw but little of the country. He reported finding on San Lorenzo Island, in front of the bay, three obscure terraces, the lower one of which, at a height of 85 feet above the sea, is covered by a bed a mile in length almost wholly composed of shells of 18 species now living in the adjoining sea. He found a bed of more weathered shells at an elevation of 170 feet. Among the shells at 85 feet above the sea he found some thread, plaited rushes, and the head of a stalk of Indian corn. From these facts he concludes that within the Indo-human period there has been an elevation of 85 feet. [These observations by Darwin have been often quoted, and only last year an excursion composed of professors and students from the School of Mines at Lima visited the island to study these terraces, and failed to reach a definite opinion in regard to the value of Darwin's conclusions.]

ObSERVations at SAN LORINzo IsLaNd BY Dana.

Fortunately, the views of Darwin have been competently criticized by Dana, who (1840) visited the locality as a member of the Wilkes

In northern Bolivia Arthur. F. Wendt has observed that the glaciers of Bolivia Arthux 1. Wenation of about Illimani and Sorata have their lower termination awn to 15,000 feet. (Proc. 18,000 feet, and that the ancient glaciers reached down to Amer. Inst. Mining Eng., 1890, vol. 19, p. 85.) Agassiz (1868), It Whatilley remembered, regarded the clays and superficial depo as glacial deposits, but later recognized his error. 
expedition. His writings on this question seem to have been overlooked, or are at least not so well known as those of Darwin. He doubts the conclusions of Darwin, and says that the San Lorenzo shells are in an irregular bed and not stratified, but are spread out just underneath the soil, and, moreover, there is an absence of an inner cliff on the island, and nothing was seen which could confdently be referred to as terraces. He studied the sea cliff on the front of the delta formation to the south of Callao at a place where it is from 45 to 65 feet high. In this cliff he found remnants of trees and in an upper layer, comminuted recent shells. He regards this cliff as furnishing evidence of an elevation since the beds were deposited, but says that to fix the time may require some further attention than the facts observed.

\section{Prefistoric Indian Vullage at ancon.}

A short distance to the north of Callao is the small port of Ancon. Archeologic researches have made known to us the very interesting remains of a fishing town of at least great antiquity. These remains and especially the interred mummies are but a few feet above the present beach. The proximity of Ancon to Callao precludes the probability that an elevation of the coast at Callao which would have raised San Lorenzo Island 85 feet would not have affected Ancon, and the writer wishes to adduce this as the most definite proof obtainable that the coast in that vicinity has remained nearly stationary during the Indo-human period.

\section{Onservations at Arion by Lmedtenant Freyer.}

In a letter to Charles Lyell, ${ }^{a}$ Lieutenant Freyer says that to the south of the Morro of Arica, on indistinct terraces, wherever the rock is exposed there are Balani and encrusting Millepora, and that at a height of about 20 to 30 feet they are as abundant and almost as perfect as at the shore. At upwards of 50 feet they still occur, but are abraded by the blowing sand, and there are traces of them at still greater heights.

\section{Obstertamions at ARTOa by Forbes.}

From Mejillones, in Chile, northward to Arica Forbes found at intervals shell beds containing exclusively shells of species now inhabiting these waters. These shells are at small intervals above the successful not reach a height of 40 feet. He stated that he was not of the Morro finding Balani and Milleporas attached to the sides of the Morro of Arica, and argues that no very perceptible elevation

${ }^{a}$ Geol. Proc., Vol. II, p. 179, published 1835, can have taken place during three hundred and fifty years as is shown by the position of Indian tumuli. He called attention to how shells may be transported inland by human agencies, by birds, winds, and drifting sands, and advises caution in accepting the mere presence of shells as a proof of elevation.

Observations in Northern Chilt by Alexander Agasstz and L. F. Pourtales.

In line with the statements by Lieutenant Freyer it may be noted that in northern Chile, in a ravine 20 miles inland from Pisagua at Beringuela (at Tilibiche), at an elevation of 2,900-3,000 feet, "recent corals" were found by Agassiz, who says that they indicate an inland sea connected with the Pacific Ocean, and that there is accordingly reason to believe that the continent has been raised "within a comparatively recent period."

The corals were described by Pourtales. It is stated that they were fossilized into a compact limestone and consisted of two new species. One was referred to a genus not represented in any lower strata than the Tertiary, and is not now living on the Prcific coast of A merica The other species was referred to a genus which had up to that time been described only from Jurassic and Triassic formations.

The writer wishes to call attention to the fact that the fossils do not date the "comparatively recent period" and do not furnish evidence which is more convincing than the relations of the Tertiary sediments, which are widely distributed in the coast region.

Rapid Reconnaissance of the Tertiary and Quaternary of the COAST.

The writer in traveling through the coast of Peru studying the geology in relation to the underground waters, observed the occurrence and distribution of the Tertiary formations in so far as was possible in the time allotted to his work, and has outlined the occurrence of the formations in the bulletins by him published by the Corps of Enorineers of Mines of Peru. From what he has written the following summary, which includes a few modifications, is presented with the hope that future observers may use it to correct and amplify a lnowledge of the subject.

\section{TRETTART OF THE NORTHIRN COASTAX PLAIN.}

\section{The Amotape formation.}

This name was given to the formations which are exposed near

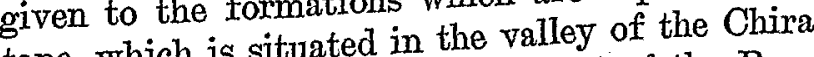
the village of Amotape, which is situated in the valley of the Brea River and is particularly well seen in the western end of the 
or Amotape hills (see pl. 2). The lithologic characters of the beds vary considerably, consisting of shales, sandstones, conglomerates, and in some places beds filled with shells and occasionally there are coral reefs. The changes observed in the nature of the formation are due to the varying distance from the shore at which they were deposited and to the deepening and shallowing of the water during the time of sedimentation. It is probable that the materials were derived from the mountainous area which during Tertiary time formed the ocean shore to the east, approximately where now are the foothills of the Andes.

The strata of the formation are not much lithified and the shales and sandstones grade into each other and into conglomerates. In the Brea hills the Amotape formation has been uplifted in an anticline, giving good exposures where the stream valleys have been eroded. The thickness of the beds has not been studied carefully, but from the outcrops seen it is safe to say that on the average it is not less than 1,000 meters, although the thiclmess may be much less in some places and greater in others, depending upon the distance
from the Tertiary shore.

Fossils are very abundant and well preserved at many places, one of the most noticeable being a large oyster which is found in such great numbers that it is used locally for burning lime.

time is petroleum mineral substance which is exploited at the present places is petroleum, of which there are superficial indications at two places called la Brea and la Breita. The productive localities are Negritos, Lobitos, and Zorritos located on the coast. Besides these some prospecting has been done farther inland. It has been reported this coal has been found at various localities within the limits of is a lionite, an. That which the writer examined at Bahia de la Cruz is a lignite, and prospecting failed to reveal a bed of any importance. the writer has been assured that north of Sullana, at the base of the Brea hills, a good quality of lignite has been found and of sufficient thickness to warrant its extraction. However, the bed has prove its commercial value. exploration would be necessary to rious mineral salts, value. The Amotape formation contains vaobtained from salts, especially gypsum, which render the water throughout the plainfit for domestic uses. The formation extends into the table-land to the from the Ecuadorian border southward. ther south, but to the east of Pita. Undoubtedly it extends farhave not been studied by the are obscured by drifting sands and nection that studed by the writer. It may be noted in this conindicated a recent in his geologic map of Ecuador has erroneously Brea hills.
In the Brea hills the formation has been thrown up in an anticline. To the south in the plains region the formation is relatively horizontal. To the north of the hills there are steep dips and local folds. These may be well seen along the valley of the Tumbez River and in the stream which empties into the ocean at Boca de Pan. It is interesting to note that the direction of the Brea hills is almost at right angles to the trend of the Andes and parallel with the border of the Gulf of Guayaquil and with the coast of the Province of Tumbez, which forms the southern part of the Gulf of Guayaquil. Moreover, the direction of the dips to the north of the range of hills suggests that the folding which produced them was actuated from the north.

The writer has not examined the axis of the range, but has been assured by travelers that it contains igneous rocks. Where the Tumber Valley merges from the flank of the hills there are some exposures of granite, which the writer saw and the presence of which was also noted by Grzybowski, but this granite may be older than the Tertiary. The anticlinal structure of the range of hills may be due to the eruption of igneous rocks which form the axis, but the writer did not see anything to indicate this at their western termination, and he is inclined to believe that it should be correlated with the subsidence which produced the embayment of the coast in the

region of the Gulf of Guayaquil.
Grzybowski was the first to study the Amotape formation, and what the writer has included under the name "Amotape formation" has been divided by Grzybowski into the Heath stage, which he calls "Lower Miocene," and above it the Zorritos and Talara stages, which he calls "Upper Miocene." He also identified, principally upon stratigraphic grounds, the Ovibos stage, which he refers to the Oligocene. The exposures which he included in this stage have not been seen by the writer, who regrets that he did not have access to Grzybowski's paper until after his own manuscript was written. It will be remembered that Raimondi sent some fossils from Paita to Gabb for determination; the localities from which they were collected were unfortunately not sufficiently specific to show whether they were from the Amotape formation or not. A collection of fossils from Zorritos was also described by Nelson, who made no special determination of their age other than late Tertiary, as suggested by the title of his paper.

Pliocene formation at Paita.

the writer observed two forIn the sea cliff at the port of Pormity. The lower he considered to incipally of sand in imperfect be the Amotape. The upper consists principally of sand the bay the writer made 
a sketch (fig. 5) of the relation of these two formations, and upon sailing southward made a similar sketch (fig. 6) showing the relations of the bed as seen after rounding the point. The presence of the bubonic plague at Paita during the writer's visit, and especially the establishing of the hospital to the west of the town, prevented a thorough examination of the locality. Grzybowski, in his article, mentions some shales cut by minute quartz veins which he found outcropping to the west of Paita near Paita Point. These shales, which were not well seen by the writer, were included by him in his sketch as a part of the Amotape formation. - The division between the Amotape and upper formation shown in the sketch corresponds approximately with the dividing line between the shales and sandstones of Grzybowski's section at Paita ${ }^{a}$ (fig. 7). Grzybowski has described what he calls the "Paita stage" from the locality at Paita, and if it had not been for this the writer would apply the name Paita formation to the upper one, which he has differentiated.

The age of the beds at Paita was not well determined by the fossils which Gabb received. He states that some of the fossils were extinct forms, and that the remainder appeared to be Pliocene. Grzybowski assigned the Pliocene age to his Paita stage. The writer thinks that the unconformity which he has shown in his section is unmistalzable, and that accordingly he would call the upper beds Pliocene. The extent of this formation has not been determined with certainty, but it apparently occupies the upper portion of the table-land of Paita. To the north, in the plains around la Brea hills, it is not to be found in extensive areas, since the good exposures which were seen all belong to the Amotape formation The Brea hills were perhaps above the level of the sea during the time it was the level It may be more appropriately expected southward, underlying the desert of Sechura.

${ }^{a}$ Original figure in Nenes Jahrbuch für Mineralogie, Beilagebani XII, Pl.
TERTIARY OF THE SOUTH CENTRAL COASTAL PKAIN.

\section{The Pisco formation.}

In the low hills to the north of Pisco, which is called "Cerro de Tiza" (meaning chalk), there are exposed white and yellowish rocks which have a calcareous aspect much like chalk (see pl. 4). At the end of the bridge over the Pisco River they may also be seen, and at this place they have steep dips and strike to the northwest. This structure is continued into Cerro de Tiza, and crosses the Pisco River to the south until the rocks disappear beneath the sands of the plains toward Ica. Many outcrops of this formation may be seen, especially in the landscape to the south of the railroad station at mile 18 , but there the beds are practically horizontal. In the Ica River valley the same formation is found resting on igneous and older stratified and metamorphic rocks. In a hill to the west of the Hacienda Ocucaje, in a hill called "Cerro Blanco," the writer saw the remains of a whale embedded in the Pisco formation. There

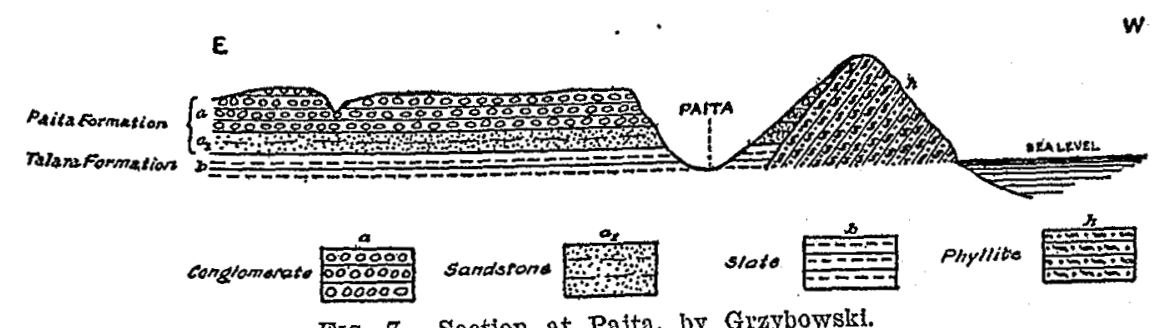

FIG. 7.-Section at Paita, by Grzybowskt.

was also some strata in which a few marine shells are found and was also some strata in which a few marine shells are found and that they have no commercial value. Farther south in the valley that they have no commercial value. Farther south in the valley io the Grande which flow past Palpa river. The tributaries of the Rio Grande which which the formaand Nazca have cut deep valleys, in the walls of which the formation is seen to contain a mixture of rounded stones in a matrix of sand and clay materials, but with a sufficient amount of the white chally matter which characterizes the formation to demonstrate that it is only a littoral phase of the Pisco formation.

The plains to the east of the The Pisco for where the remains of a whale were seen by the writer, port of Lomas, where the remains out the plain a conglomerate of maand in one of the valleys which cut the plain a conglomerate of marrow and the rine shells was found. To the southward the plains narrow all area mountains come to the seacoast, but at Chala there is af variegated of Pisco formation in which the beds consist largely of vare clays.

In the northern part of the plains, to the east of the Cañete, the Pisco formation was found presenting a littoral phase, but containing 
some of the white chall material and some beds of impure concretionary limestones similar to what occurred at the type locality near Pisco. The so-called chall material was analyzed by the Corps of Engineers of Mines and found to consist principally of silica, with small amounts of lime and alumina. A microscopic examination showed it to contain many diatoms and what appeared to be volcanic ash.

In traveling by steamer from Pisco to Lomas the Pisco formation can be seen forming the sea cliffs and rising to the table land of Ica.

Although some fossils have been found, they have not been studied critically. The age of the Pisco formation is not surely known. The writer has assigned it to the Pliocene provisionally, since it is overlain by deposits which are probably of Pleistocene age, and there is no information which shows the necessity of assigning it to an
earlier time.

\section{TERTIARY OF THE SOUTHIERN COASTAL PLAINS.}

\section{The Moquegua formation.}

The writer has given this name to the formation which occupies the southern coastal plains. It has been described locally, by Forbes and others, as already mentioned in this paper, but no one had journeyed sufficiently over the plains to learn that it was coextensive with them. The strata which constitute it can be studied conveniently in the valley of the Moquegua River, especially near the town of the same name. It is also well exposed in the valleys of all the streams which cross the plains, since they have cut deep canyons. The eastern limit of the formation is at the foothills of the Andes, and the western limit is formed by the chain of coast hills. It reaches to the Pacific Ocean in the interval between the coast hills of Peru and the Morro of Arica, which is the northern extremity of the coast hills of Chile. The character of the rocks which constitute the Moquegua formation has been well outlined by Forbes. They consist of sands with some clays, a large quantity of detrital material derived from igneous rocks, but especially noticeable are the thick beds of volcanic material which appear to have been deposited in water and interbedded with sands. In the valley of the River Vitor, which descends from the Andes past the volcano Misti which is located near Ariquipa, beds of lava may bo seen which have descended from the volcano and extended over the plains, where they form a capping on the Moquegua formation. The age of the volcanic determine the ainly known, and there has been no opportunity to been fou the aro the Mormation, since no fossils have been found. It is generally stated that the volcanoes of southern
Peru began their activity in Tertiary times and some of them are still active, although no great lava flows have come from them in recent times. The writer has provisionally assigned the Pliocene age to the Moquegua formation, thus making it contemporaneous with the Pisco formation to the north. There appears to be no reason for considering it as of greater age, and in outlining the history of the coast the Pliocene age seems for the present satisfactory.

The thickness of the Moquegua formation is variable, since it was apparently deposited in a trough between the coast hills and the foothills of the Andes (see fig. 8). From measurements made in some of the canyons a thickness of 1,500 feet may be assigned.

\section{RUATRRNARY DEPOSITS.}

\section{Pleistocene.}

The Pacasmato formation.

At Pacasmayo, in the southerm part of the northern coastal plains, the sea cliff consists of stratified conglomerates mixed with sand and occasional clay beds (see pl. 3). The formation is also well exposed at the mouth of the Jequetepeque and along that stream inland. At Eten the sea cliff consists of a homogeneous sandy clay. To the north of Eten for a considerable distance the coast is low near the shore and there are no good exposures, so there are no good exp been able to trace the Pacasmayo formation

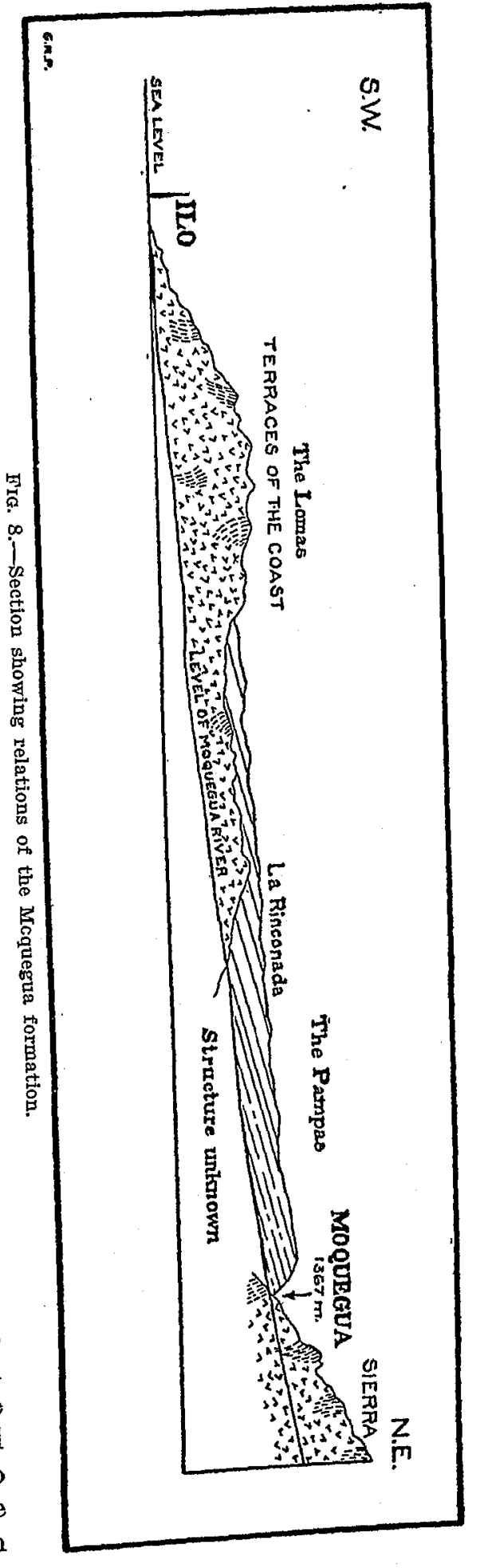


farther in that direction. To the south of Pacasmajo the coastal plains narrow until the mountains Throughout the shore south in the valley of Viru. is roprest this extent the Pacasmayo formation relationsented in its various phases. The age and relations of this formation will be more clearly understood when it is considered in connection with which Barranco formation next to be described, with which it has been correlated (see fig. 9). It is to the relation that in the region of the Sechura desert ern relations of the Tertiary formations of the northern part of the northern coastal plains and the the driftino of the southern portion are obscured by the drifting sands, which obliterates any exposures relief.

\section{BarRanco Formation.}

At the valleys of the Pativilca, Huaura, Chancay, and Rimac rivers there are sea cliffs cut in what appear to be raised delta formations. In other valleys to the south and north smaller areas of a similar formation may be seen (see pl. 4). At Tambo de Mora the sea cliff has the same character as athe mouths of the rivers, but there the formathe valley inland and northward continuously to area, which of the Cañete. The writer regards this area, which constitutes a part of the south-central coastal plains, as furnishing the key to the proper understanding of the Barranco formation It un doubtedly lies upon the Pisco formation, although its relations to the latter south of the Chin, although are not very clear because of the intervention of the wide stream valley. Its relation to the Pisco formation may also be seen in the Cañeto Valley. The character of the seen in the Cañete Valley. cementation in the materials and the degree of tions is similar.

No fossils have been tion of comminuted been found with the excepof trees. The shells and occasional branches age to these writer has assigned the Pleistocene sediments and bosits and would correlate the coarse in the form and structure of deltas with the in- creased volume of the streams and the erosion which accompanied the glacial period.

\section{RECENT FORMATIONS OF THE COAST.}

The recent formations consist principally of materials transported by the rivers and deposited at their deltas and of the wind-blown sands which sweep over the coastal plains. In addition there are places along the coast where the materials eroded by wave action and transported by ocean currents have accumulated in the form of recent beaches. The beaches here referred to should not be confounded with the raised beaches, which will be discussed later in this paper. The deltas of the coast are usually unsymmetrical because of the northward direction of the coast currents. In many cases the deltas blend with the recent beaches, due to marine action. The delta of the Tumbez River, which is the northernmost of the coast, lies in front of a clearly defined sea cliff. Similarly the delta of the Chira River blends with the recent sea beaches lying in front of a sea cliff, which extends from the mouth of the river northward to Negritos.

The r. deltas worthy of special mention. In the extent of mountainous coast between the northern coastal plains and the south central coastal plains there are a number of localities where recent beaches may be found, and in this part of the coast the Quaternary and Tertiary deposits already described are absent.

To the north of the Santa River there is an area of recent beaches in which salt is manufactured by evaporation, the brine being obtained by digging shallow pits, into which it filters. The area of the beaches is extensive, and the slight depth to the salt water indicates the fact that they are but slightly above sea level. The materials which have a the beaches have largely been brought by the Santa River and drifted northward by the ocean cul santa River has extended seaward and so connected an island with the mainland. In Chimbote and Samanco harbors one may see an area of drowned mountainous coast. At some former time the two bays were one, but the accumulation of and has formed a bar and connected one of the larger islands with the mainland. The front of the raised delta of the Rimac River, on which Lima, the capital of the country, is located, has been largely cut away by marine erosion, and the currents have

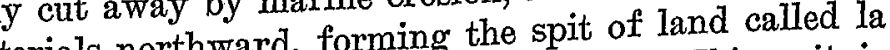
drifted the materials northward, forming the harbor of Callao. This spit is
Punta, which is a feature of the

${ }^{a}$ A description of the Rimac delta by the author may be for 1905 . 
gradually extending, and lying between it and the island of San Lorenzo there is now a bank on which the waves break. The ultimate outcome of this process may be a connection between the mainland and San Lorenzo Island.

At Port Cerro Azul the rocky promontory which protects the port was once an island. It has been connected with the mainland by the growth of the delta of the Cañete River. Similarly there are a number of delta deposits and recent beaches in the southern part of the coast. In riding on a train from Mollendo along the beach before the ascent of the range of coast hills is made one may see recent conglomerates, which have been partially eroded, and marine beaches in process of formation.

The material transported by the winds has in places accumulated in areas of sand dunes which are moving with the general direction of the wind, but the more common condition is to find the sand forming a mantle on the hill slopes and rounding the contours of the hills, and often rising well up on to the sides and in some cases even to the crests of the mountains. The most extensive area of drifting sand is to be found in the Sechura Desert and the plains to the east of Piura. In the latter place the sand is held by a sparse growth of drouthresisting trees and bushes. The height of this drifting sand as seen in the topography of the country reaches perhaps 200 feet, but proof of its great thickness was obtained when a well was drilled in it. The drillers could hardly be expected to distinguish the point at which they passed out of the wind-drifted sand, but they found nothing but sand and had no difficulty in driving the casing of the well to a depth of something over 3,000 feet.

If one refers to the map of the coast of Peru and observes the configuration of the coast in the region of the desert of Sechura, he will see that the direction changes more to the west so that the winds blowing from the Pacific have a clean sweep over the desert, and the sand is carried inland by the winds in a nearly northern direction. It is this fact which accounts for the low relief near the coast where the sand has been derived and the great thickness of the Aeolian deposits st of Piura.

In the south central coastal plains there is a conspicuous area of sand hills between Ica and Pisco; also some smaller ones to the west of Ica and Palpa. There are numerous areas of migrating sand hills tudes, the surface oftal plains, but none of the dunes attain great altidunes as over a $\theta$ of the plain is hard and the sand moves in crescentic traveling from Mollend These dunes may be seen from the railway in remembered by the southern coastal ash or sand tore is a large amount of white volcanic ash or sand derived from volcanic materials.

\section{RAISTED BEACHES.}

The action of the sea in cutting cliffs may be well observed along the coast of the northern coastal plains, where the Tertiary formations at many places rise in sheer bluffs. The same process has been in operation at other places on the coast where elevation has taken place and the cutting action of the sea is displayed in a succession of marine terraces. These are especially noticeable on the coast between Pisco and Lomas, where the Pisco formation displays approximately ten distinct terraces rising to a height of perhaps 1,000 feet. Along

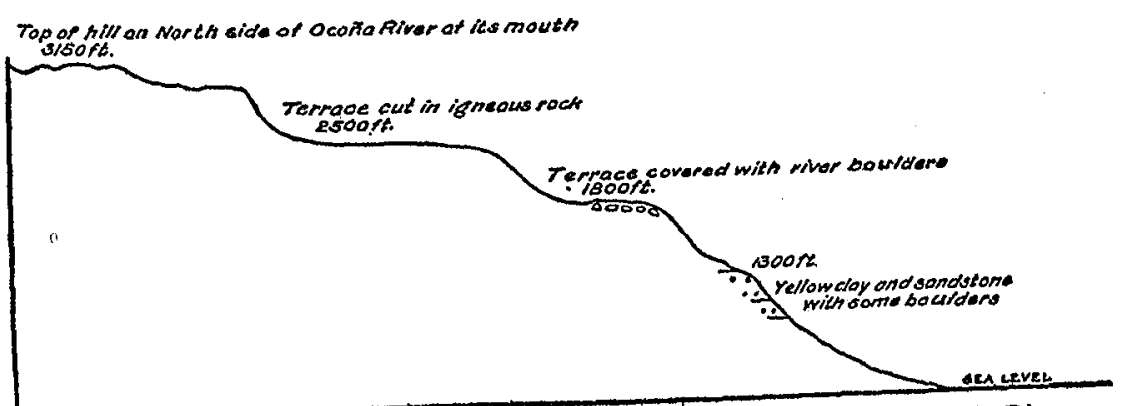

FIG. 10.-Section showing marine cut terraces at the mouth of the Ocoũa River.

the southern part of the Peruvian coast in front of the range of coast hills where the rivers have cut their canyons through, there are terraces in the igneous rocks which constitute the hills and also in the remnants of what were once delta formations of these streams. The terraces at the mouth of the Ocoña River, as seen by the writer and measured with an aneroid, are represented in the following sketch fig. 10). The the highest one which was found on the coast.

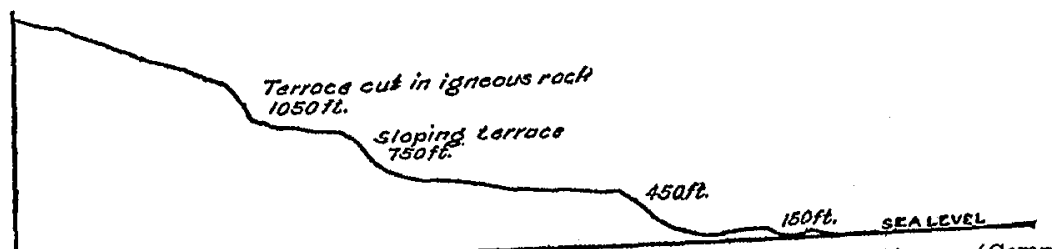
Fig. 11.-Section showing marine cut terraces at the mouth of the Ilo River. (Compare
fig. 8. )

The railroad station, Tambo near Mollendo, on the Southern Rail and is situated on the north side way, has an elevation of 1,000 leet and is sibuated on thace which must the River Tambo near its mouth, on an extensive terrace wh its origin is have attracted the attention of many travelers, although the writer's not explained in any scientific article which has come to the witer's notice.

The terraces south of the Mlo River, near its mouth, are indicated in the above sketch (fig. 11). 


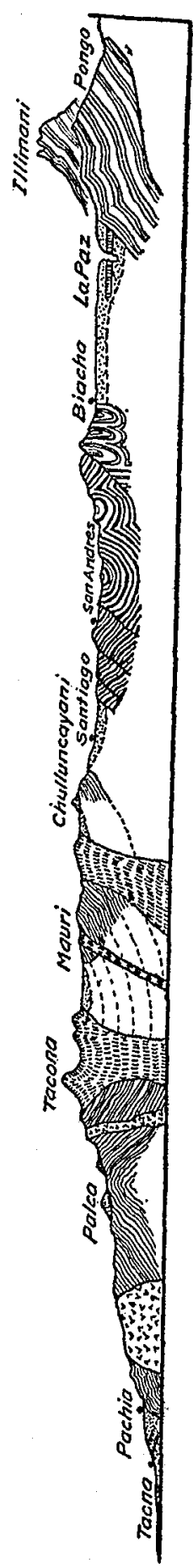

Incidentally it may be said that at the mouth of the canyon just north of Pisagua in Chile similar terraces may be seen, the upper one being at an elevation of something more than 1,000 feet.

These terraces, taken together with the elevation at which the Pliocene Tertiary formations on the coast are found, record the rising of the land. Accordingly, the upper terraces may be Pleistocene and the lower ones Recent, but there is nothing to indicate two periods of movement, and the spacing and disposition of the terraces cut is the Pisco formation indicate a gradual elevation.

s

A

$\vec{x}$ 苗

这

Q

\section{Geologtc Stettons of the Andes.}

SECTION OF SOUTHERN PRRU, ARICA TO IA PAZ, BY DAVID FORBIS (1860).

If the general section of Peru by Forbes ${ }^{a}$ (fig. 12) is divided so that it may be compared with the succession of zones parallel to the trend of the Andes, as distinguished by Steinmann at a later date, the following may be enumerated from the coast toward the interior:

1. Mesozoic sediments with interstratified porphyries of the coast range (at Arica).

2. The Tertiary (and diluvial) formation of the coast plains with trachytic tuffs and ash beds.

3. The diorites of post-Cretaceous (post oolitic) age.

4. The Mesozoic sedimentaries with interstratified porphyries of the western slope of the Cordilleras cut by diorites.

5. Volcanic trachytes and trachytic rocks of the Cordillera Occidental cutting the Mesozoic sedimentaries.

6. Zone of Paleozoic (Carboniferous and Devonian) sediments of the Titicaca basin with later "diluvial," including a bed of interstratified trachytic tuff.

\section{Zone of slates (Silurian) and granites.}

Comparing these zones with those enumerated by Steinmann, later to be mentioned, it will be seen that there are no granitic rocks in the coast and that the coast range which extends from Arica southward into Chile is not comparable with the coast range at Mollendo. In fact, there is a gap between the two just north of Arica. In other respects the zones are quite comparable excepting for the difference due to the structure of the Titicaca basin. The rocks which Forbes called "Permian" or "Triassic" are now called "Cretaceous" by Steinmann, and above are included with the Mesozoic.

SECTION THROUGH THE DEPARTMENT OF ANCACES, BY RAIMONDI (1873).

It should be remembered in considering this region that the Cordillera Occidental divides into two branches, the western known as the "Cordillera Negra" and the eastern or principal one, the "Cordillera Blanca." Raimondi made no section, but from his writings one may recognize the following zones:

1. Granites and syenites of the coast.

2. Mesozoic sediments with porphyries and diorites. The sedimentaries are rare in the coast but are found more abundantly inland.

3. The diorites are seen in the Cordillera Negra and the Cordillera Blanca up to the limit of snow, but not in the crest of the range or axis. The eruption of the diorites posterior to the Jurassic removed and lifted some formations of the Cretaceous and introduced metallic veins.

4. Trachytes anterior to the present, there now being no volcanoes. These rock ant in the Cordillera Negra but not forming peaks in the latter. Raimondi thinks the eruption of the trachytes occurred at a time when the two Cordilleras formed one mass and that they have since been separated by erosion.

5. In the valley of the Maranon are found older sediments, talcose slates with quartz veins which are referred to the Silurian. A small area of similar rocks was also noted at Pallasca on the western slope of the Cordillera Nevada.

SECTION OF ICUADOR, BY WOLF (1892).

Reviewing the geology of Ecuador as outlined by Wolf and coordinating the data in such a way as to compare it with the sections already given of Peru we find the following more or less distinct zones:

1. The Tertiary and Quaternary formations of the coast of marine origin.

$88292-$ SM $1908-28$

\footnotetext{
"Original in Quart, Journ, Geol. Soc. London, Vol. XVII, PI, III,
} 


\section{GEOLOGY OF PERU-ADAMS.}

2. The Cretaceous, principally in the western Cordillera ${ }^{a}$ of Ecuador. This rock presents three facies: (a) Toward the coast and in the hills of the coastal plains, limestones, siliceous limestones, and shales with variegated sandstones and quartzites; $(b)$ in the mountain basins, sandstones, and clay shales and slates; $(c)$ conglomerates and breccia form conglomerates, sandstones, and clay shales predominating in the Cordillera.

3. With the Cretaceous are associated porphyries and greenstones, some being contemporaneous and others post-Cretaceous. With these igneous rocks, of which the diorites are the most common, are associated the mineral deposits.

4. The gneisses and crystalline schists of Archean age principally in the eastern Cordillera. There are granites in genetic relation with the gneisses and syenites in genetic relation with the schists.

5. The volcanic rocks which are related to the still active group of volcanoes of Ecuador. The volcanic tuff's contain bones of Quaternary mammals, but the volcanic activity may have commenced in the

6. Lacustrine Tertiary in some of the inter-Andean basins.

SECTION FROM LIMA TO CEAUCHAMAYO, BY GUSTAV STMINMANN (1904).

According to Steinmann there are in Peru six zones, well marked by their distinct geologic composition, which extend parallel to the axis of the Cordilleras. These zones are designated as follows:

1. The granitic-Tertiary zone of the coast

2. The first zone of Mesozoic sediments.

3. The zone of diorites.

4. The second zone of Mesozoic sediments with a porphyritic facies

5. The third zone of Mesozoic sediments with a calcareous facies.

6. The zone of slates and granites.

The first zone is not represented in the vicinity of Lima, but may be found to the south from Pisco to Mollendo. The granitic rocks are siluric or pre-siluric, cut by Mesozoic porphyries. ${ }^{b}$ The Tertiary ormations are probably Pliocene.

The second zone near Lima contains sandstones and quartzites, is Cretaceous (Notes, with some limestones. The age of the formations remains. sedimentary rocks are is in the form of an anticlinal fold. The a

${ }^{a}$ Because of the fact that the Cordilleras Oriental and Occidental in Ecuador
are not the equivalents are here spolven of as the "western"

'The writer wishes to "western" and "eastern" to avoid confusion.

should be included in this zone that the small Oarboniferous area near Pisco
In order to make clear the aspects under which the porphyries present themselves, the following explanation is offered: From the close of the Triassic, during Jurassic and Cretaceous time, a shallow sea with a gradually sinlking bottom occupied the region which to-day constitutes the western part of the Andes. In this sea, in which normal sediments were being deposited, immense eruptions of basic volcanic rocks occurred, taking the forms of flows, conglomerates, breccias, sandstones, and stratified tuffs.

The third, or diorite, zone is found on the western slope of the Cordillera Occidental. The diorites are clearly younger than the Cordillera Occidental. The sedimentaries, since they have cut and metamorphosed them. The normal diorite contains dikes and masses of a darker, more basic, and finer-grained diorite. The Mesozoic rocks which occupied this zone have nearly all disappeared.

The fourth zone includes the crest and eastern slope of the Cordillera Occidental. Here the porphyritic facies in the Mesozoic rocks is typical. The formations, Jurassic and Cretaceous, are strongly folded, and the inclination of the beds is more frequently to the west than to the east. In this region andesitic eruptions abound (for the most part quartzitic) and extend eastward into the next zone. The mineral deposits of the region are related to these andesites.

The formations gradually replaces the porphyritic facies until it becomes a great limestone formation, whe of Jurassic and Cretaceous age.

In the sixth zone granite and slate are found. Although no fossils In the sixth zone gilurian because of their resemblance to the lknown zone of Silurian in southern Peru and Bolivia.

Below the Mesozoic sediments there is a series of dark siliceous slates and sandstones, with some conglomerates, which are believed to be Paleozoic and especially Carboniferous, the existence of Carboniferous in the region being proven by finding a few characteristic fossils. lera of Peru, the red sandstones and shales, with salt and gypsum, the lower Lias, no fossils having been found as yet, and they accordingly belong to the series of Mesozoic sediments.

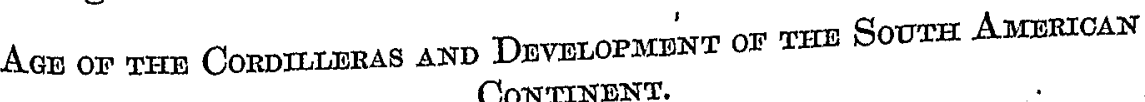
Con'minent.

In the atlas accompanying d'Orbigny's monograph there is a map of South America showing the general distribution of the geologic The map is very conventional and formations according to his ideas. The maple error as regards Peru is is of littlo value to-day. The most noticeable error as regards Pera is 
that he breaks the continuity of the Cretaceous in the Andes between northern Peru and Ecuador, so that the Tertiary of the Pacific coast connects with the Tertiary of the Amazon basin in the latitude of the Gulf of Guayaquil. D'Orbigny also published four small maps showing the development of the South American continent. He took as a nucleus a small area of gneissic and primordial rocks along the Brazilian coast. From this area the land mass developed to the northwest. After the Carboniferous he shows a land mass in Guiana in addition to the larger one in Brazil. After the Triassic he shows an isolated land mass in the eastern Cordilleras of Peru and Bolivia, and following the Cretaceous he unites the Brazilian and Andean land masses by a fringing border of Cretaceous, and shows an isolated mass of Cretaceous in Ecuador and Colombia and Venezuela. The remaining parts of the continent were formed by the addition of Tertiary and diluvial. [The maps by d'Orbigny are of only historical interest as showing the development of geological science at
that time.]

Agassiz appears to have followed in a measure the ideas advanced by d'Orbigny. He says in substance (1868) that the valley of the Amazon was first sketched out by the elevation of two tracts of land, namely, the plateau of Guiana on the north and the central plateau of Brazil on the south. It is probable that, at the time these two tablelands were lifted above the sea level, the Andes did not exist and the ocean flowed between them through an open strait. At a later period the upheaval of the Andes took place, closing the western side of this strait and thus transformed it into a gulf open toward the east. It seems certain that at the close of the secondary age the whole Amazon basin was lined with a Cretaceous deposit, the margins of observed alon at various localities on its borders. They have been Andes, in Ven lts southern limits on its western outskirt along the Andes, in Venezuela along the shore line of mountains, and also in

Orton evidently foar its eastern edge.

Orton evidently followed the ideas advanced by Agassiz, but his South America is aftical account of the geological development of "Three times the of no value to science. He says, for example: level and again were Andes sank hundreds of feet beneath the ocean

The first aln were slowly brought up to their present height." of Peru was in his letter to Raimondi made to outline the geology Cordillera is his letter to Gabb (1867). He stated that the eastern of micaceous and the elevation af thalcose slates which have been metamorphosed by veins of quartz which in thes, have also introduced numerous western Cordillera which in some places are quite rich in gold. The length of rock of much more recent age (Mesozoic). Another group of rocks, probably Carboniferous, form the great basin of Lake Titicaca, and a small spot in the heights of Huanta.

In his volume on the Department of Ancachs (1873) he elaborates his ideas somewhat more fully. He says that the first land relief produced within the limits of Peru was not the Cordillera which forms the continental divide, but the grand mountain chain which in Bolivia forms the Cordillera real and extends northward into Peru.

This grand chain is formed for the most part of talcose and clay slates and owes its relief to the eruption of granitic rocks, which, however, did not always find their way to the surface, being rare in the southern part of the chain, but in many places the eruption introduced quartz veins into the slates. Contemporaneous with this relief perhaps occurred the eruption of the granites and syenites of the coast, which in many places contain thin veins of auriferous quartz.

After the Jurassic began the exuption of the porphyries, and when the Cretaceous had begun the grand eruption of the diorites took place. Following the deposition of the Cretaceous the axis of the Cordillera was brought into relief.

A sketch of the geology of South America was read by Steinmann before the Geological Society of America in 1891. This sketch is explanatory of a map which was prepared by him for a second edition of Berghausen's Physical Atlas. Unfortunately the map is very small, and, moreover, data were not available for an accurate map. From the sketch the following points may be gathered which are of interest here.

In Devonian times, as is indicated by the sediments, there was an extensive sea embracing the larger part of South America, especially Brazil and Bolivia (and extending also into Peru).

The Carboniferous deposits were more restricted, but are known from Peru, Bolivia, and Brazil.

During the Permian, Triassic, and Jurassic the greater part of Douth Triassic and Jurassic marine deposits have been found on the western part the continent, rich collections of Jurassic fossils having been partilleras of the Argentine, Chile, and Peru.

thed triassic and Jurassic

In contrast to the small extension of marine Cretaceous being found. the Cretaceous covers a large area, marine Cretaceous being found in all parts

Thenia.

The Cordillera of South America is famous forler attention for its tions of the latest time, but it merits no smaller attention for the submarine eruptions during Meso 


\section{BIBLIOGRAPHY.} The papers mentioned in this list are referred to in the text by the
dates of publication.

1814.-Humboldt, Alexander. Voyage aux rêgions équinoxiales đu Nouveau Continent, fait en 1799-1804. Pt. I. Relation historique, Paris, 1814. Personal narrative of travels to the equin. I. Relation historique, Paris, 1814. Personal years 1709-1804, translated by H. M. Williams, published London, 1818-19. Also translation by Thomasina Ross, in three volumes (see Vol. III), pub-
lished in 1853.

1830.-Pentland, William. On the height of the perpetual snows in the Cordilleras in Peru. Edinburgh New Philosophical Journal, Vol. VIII, p. 311, 1830. 1835.-Pentland, J. B. On the general outline and physical confinution the Bolivian Andes; with observations on the line of perpetual snow upon the Andes between $15^{\circ}$ and $20^{\circ}$ south latitude. Geogr. Soc. Journal, V, 1835, pp.
$70-89$.

1838.-Darwin, Charles. "Observations of proofs of recent elevation on the by Captain Fitzro during the survey of His Majesty's ship Beagle, commanded lished in Proceedings Read before the Geological Society of London and publogical the voyage of the Beagle during America," being the third part of the geology of editions, )

1842.-D'Orbigny, Alcide. Voyage dans l'Amérique Méridionale, Paléontologie et Géologie. Vol. III, Pt. III, IV, 1842.

1849.-Dana, James D. United States exploring expedition during the years published 1849 .

1852.-Crosnier, I. Géologie đu Pérou. Notice gêologinue ser.), Vol. Ir.
s. Anelica et d'Ayacucho. Annales des Mines, Paris, 1852 (5th

1856.-Pissis, M. "Recherches sur le système de soulèrement de l'Amerique 1861.-Forbes, David Mines (1856), $5^{\mathrm{mo}}$ sér., Tome IX.

Journ. Geol. Soc., 1861, On the Geology of Bolivia and Southern Peru. Quart, Also translated into Spanish br, pp. 7-62 (with geological map and sections). Sociedad Geografica de Lanish by Edmundo Sologuren and published by the y del Sud del Perá, por Dayid, Bolivia, 1901, with the title Geologia de Bolivia 1861.-Salter Peŕ, por David Forbes.

by David Forbes. Quart. Journ fossils from the High Andes (Bolivia) collected pls. 4-5 (Palæozoic fossils).

1867.-Raimondi, Antonio. Letter to William Gabb. Proceedings Cal. Acad.
Nat. Sci., III, 1867, published.

1868.-Agassiz, Louis. Geological sketches

published in "A Journey in Brazil," by Profes. Second series, 1876. Previously

1868.-Gabb, William. Descriptions of fossor and Mrs. Agassiz, 1868.

per Amazon. Amer. Journ. Conchol fossils from the clay deposits of the 1869.-Gabb, W. M. Description of

Tertiary by W. M. Gabb. American new species of Sonth American fossils p. 25, 1869. 1870.-Orton

lished 1870.
1870.-Conrad, T. A. Description of new fossil shells from the Upper Amazon Tertiary. Amer. Journ. Conchology, Vol. VI, p. 192, 1870.

1870.-Nelson, Edward T. On the molluscan fauna of the late Tertiary of Peru. (From Zorritos, presented to Yale Jollege in 1867 by H. P. Larkin and Prof. F. H. Bradley.) Trans. Conn. Acad. Sci., Vol. 2, p. 186, 1870.

1873.-Raimondi, Antonio. El departamento de Ancachs 7 sus riquezas minerales. Lima, 1873. Parte segunda: Geología.

1874.-Conrad, T. A. Remarks on the Tertiary clays of the upper Amazon, with description of new shells. Proc. Acad. of Nat. Sci. Phila., Vol. XXVI, p. 25, 1874 .

1876- - Agassiz, Alexander. Hydrographic sketch of Lake Titicaca. Proc. Amer. Acad. of Arts and Sci., 1876. New Series, Vol. III, p. 283.

1876.-Derby, O. A., and Agassiz, Alexander. Notice of the Paleozoic fossils (from Lake Titicaca region), with notes by Alexander Agassiz. Bull. Mus. Comp. Zoology, Harvard College, 1876, Vol. III, No. 12, pp. 276-286.

1876-Agassiz, Alexander, and Pourtales, I. F. Recent corals from Tilibiche, Peru (now in Chile). Bull. Mus. Comp. Zool. Harvard College, Vol. III, p. 287, 1876.

1877.-Gabb, W. M. Description of a collection of fossils made by $\mathrm{Dr}$. Antonio Raimondi, in Peru. Journ. Acad. Nat. Sci., Philadelphia, 1877, new series, Vol. VIII, Part III, p. 263. (Contains a synopsis of South American invertebrate paleontolog $y$ and a bibliography of South American paleontology).

1881.-Steinmann, Gustav. Über Tithon und Kreide in den Peruanischen Anden. Neues Jahrbuch, 1881, p. 130.

1883.-Pflüclerer y Rico, I. Apuntes sobre el distrito mineral de Yauli. Anales de Const. Civiles y de Minas del Perú, Tomo III, 1883.

1891.-Steinmann, G. "A sletch of the geology of South America." American Naturalist, 1891 , p. 855-860. Read before the Geological Society of America Aug. 25, 1891. This sketch accompanies a map which forms a second edition of the Physical Atlas of Berghausen (Gotha Justus Perthes). Abstract and discussion, Bull. Geol. Soc. Amer., 1891, Vỏl. III, p. 13. Full paper in American Naturalist.

1892.-Ulrich, Arnold. Palaeozoische Versteinerungen aus Bolivien. Beilageband. Neues Jahrbuch, Vol. VII, p. 5, 1892.

1892 -Wolf, Theodoro. Geografía y Geología del Ecuador. Publicado por orden del Supremo Gobierno de la Repablica (with 2 maps). Leipzig, 1892. 1897-Balta Bol. de la Soc. Geogr. de Lima, T. VII, Nos. 1-2-3, Vol. for 1897-8.

1897.-Gerhardt, K. Beiträge zur Kentniss der Kreideformation in Venezuela und Peru. Neues Jahrbuch, Beilageband XI, 1897.

1899.-Grzybowski, Josef. Die Tertiärablagerungen des nördlichen Peru und ihre Molluskenfauna. Neues Jahrbuch, Beilageband XII, 1899.

1899 Revista Cientifica, Tomo II, Lima, 1899.

1899.-Peruvian Meteorology, Solon I. Bailey and Idward C. Pickering. Cambridge, 1899. Annals of the Astronomical Observatory of Harvard College (at Arequipa, Peru), vol. 39, part 1. (See Chapter II on configuration and heights of the Andes, limits of perpetual snow, etc.)

a de península de Paran

1902-Raimoni Antonio Tomo IV. Estudios mineralogicos J geologicos (primera serie), (1902), edited by Jose Balta. 
430 ANNUAL REPORT SMITHSONIAN INSTITUTION, 1908.

1903.-Paulcke, W. Uber die Kreideformation in Südamerika und ihre Bezie-

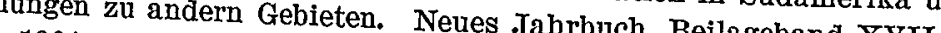

1904.- Steinmann, Gustav. Obserno mayo. Bol. del Cuerpo de Ing. de Minos del Pero 1906.-Steinmann, Gustav, Die Entstehung der. 12 .

Coro-Coro (Bolivia). Rosenbusch 1906 , pp. 335-368.

1901-4. Informe del InGobierno 8 Fomento.

Quartare vergietscherung der A den in Bollyen und .

Mittel-Peru, Reve zur kentniss der Kreideformation in -

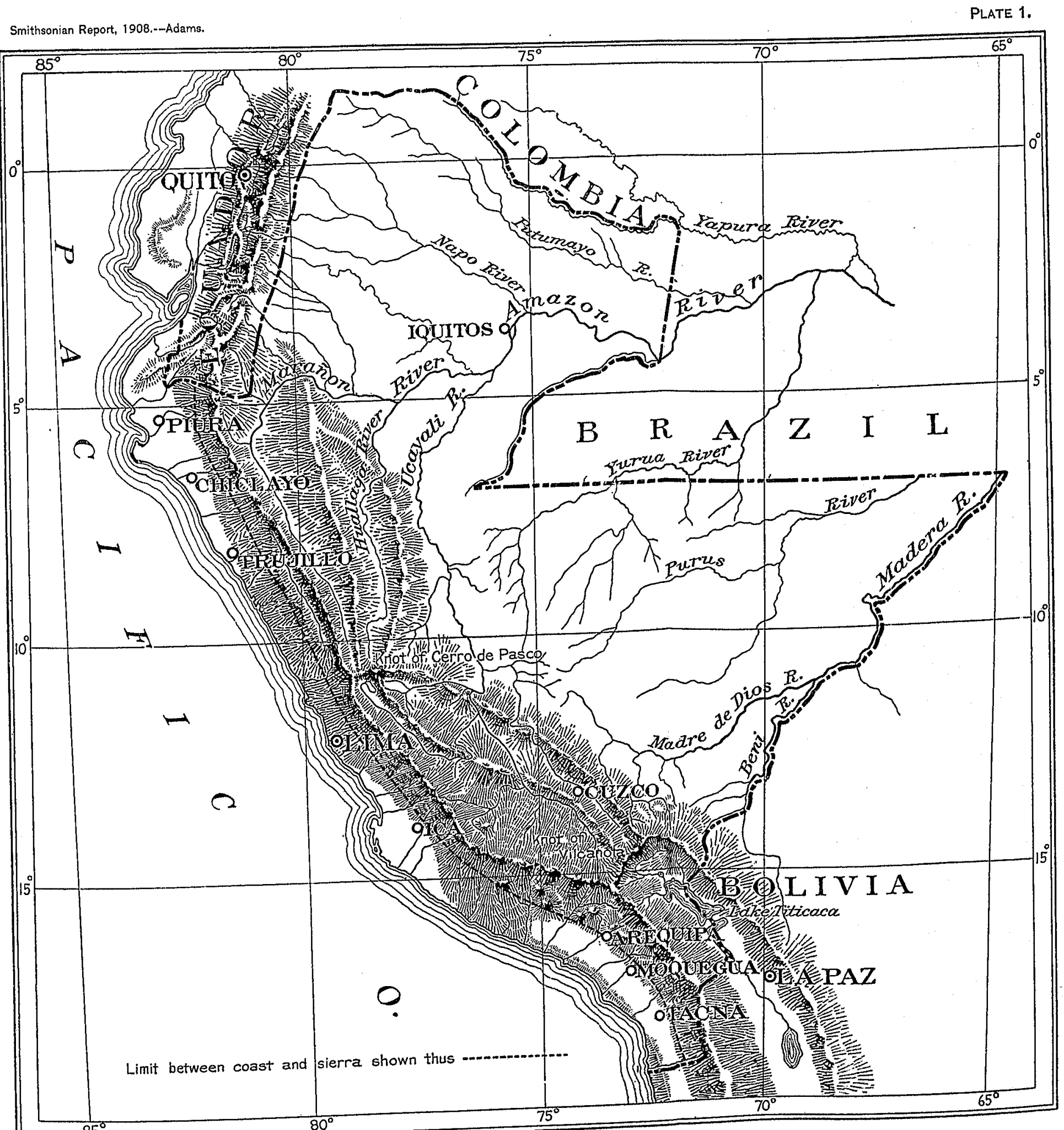

MAP OF PERU, SHOWING THE CORDILLERAS OF THE ANDEs. 


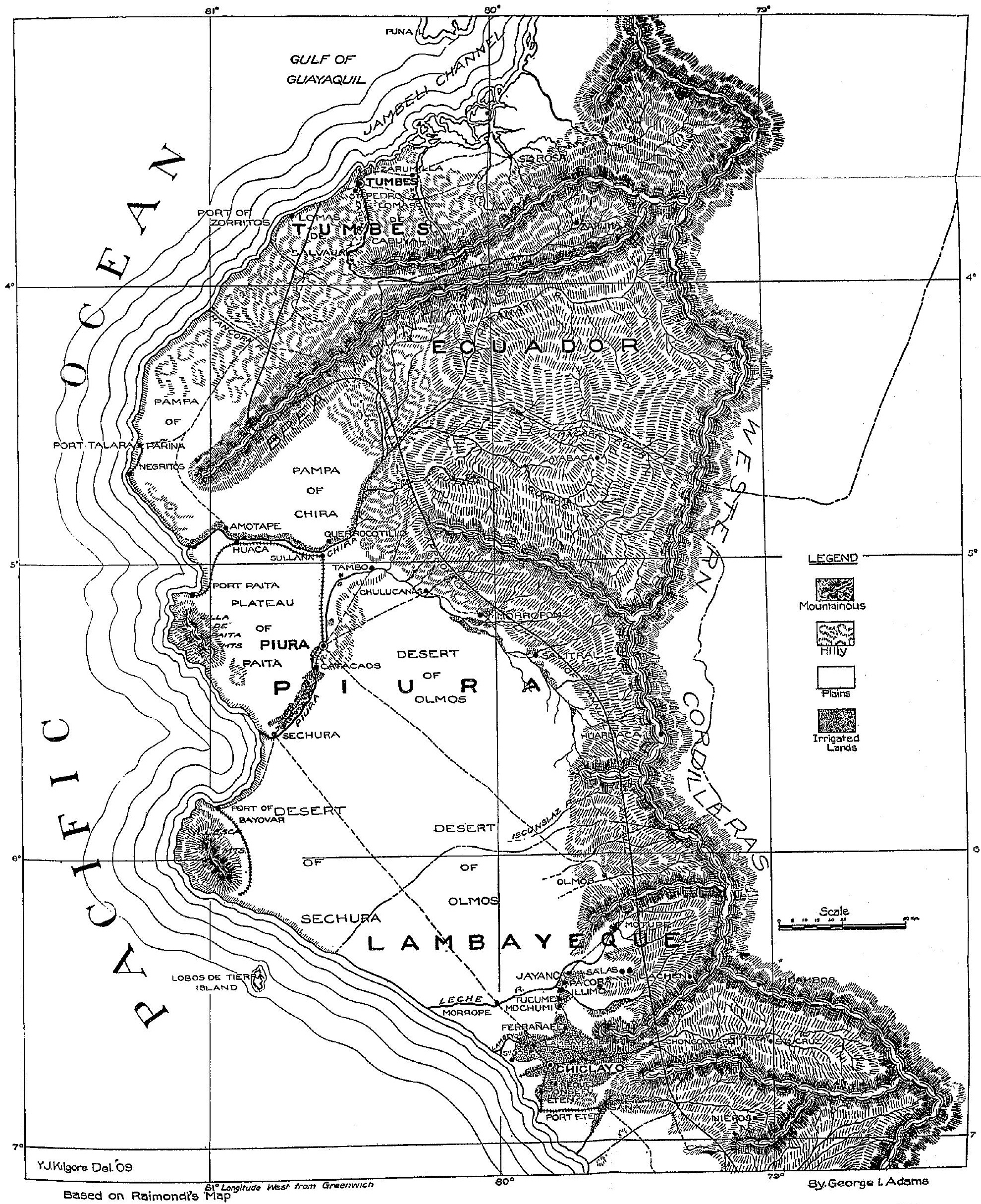




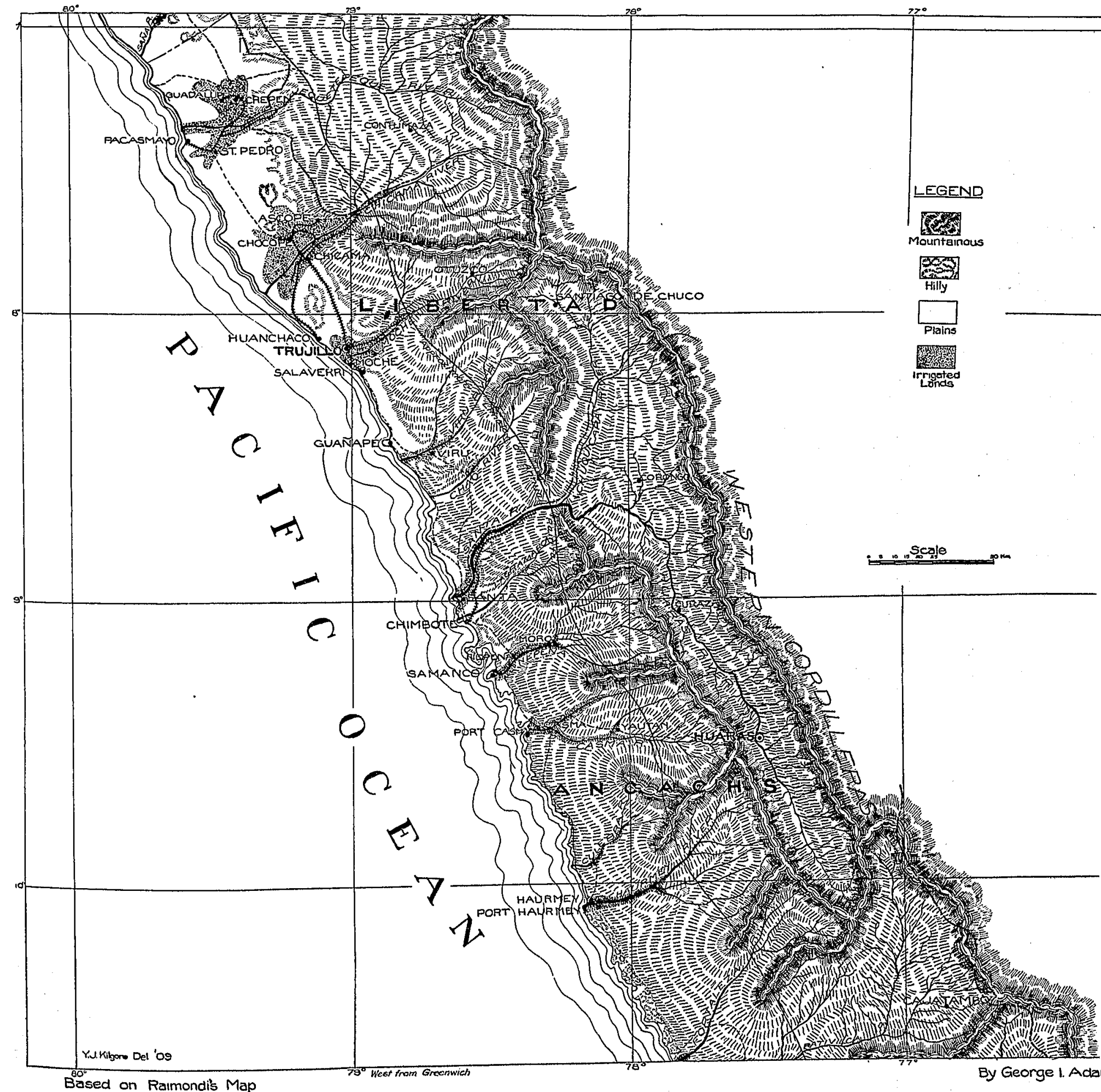

hydrologic map of the North Central division of the Pacific slope of Peru. Departments of libertad and Ancachs. 


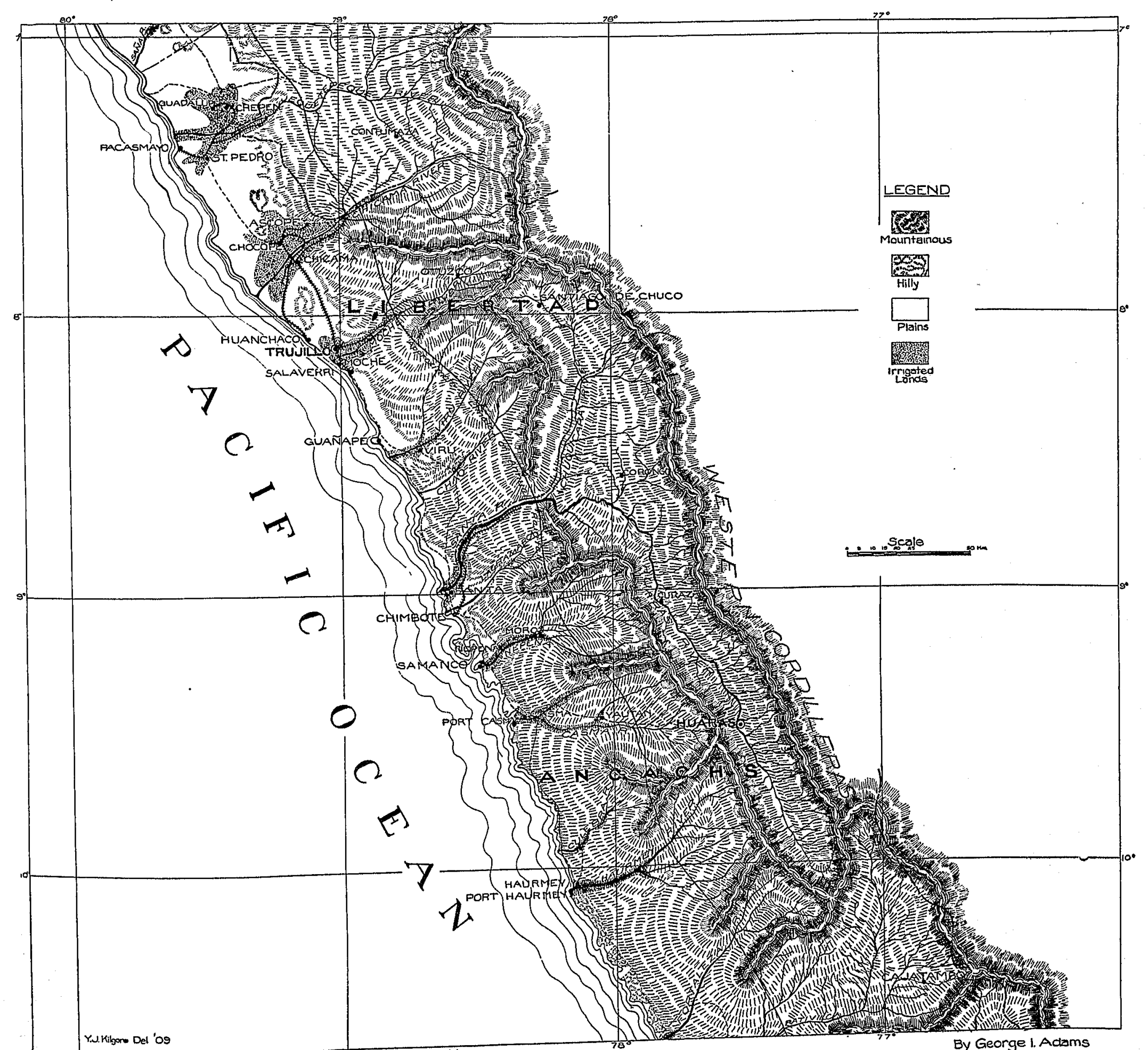

Based on Ramondis Map

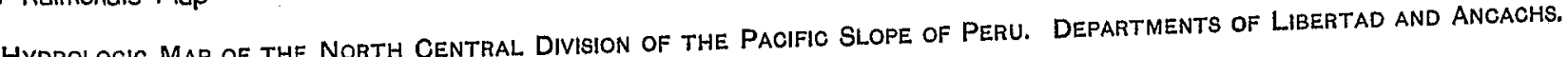




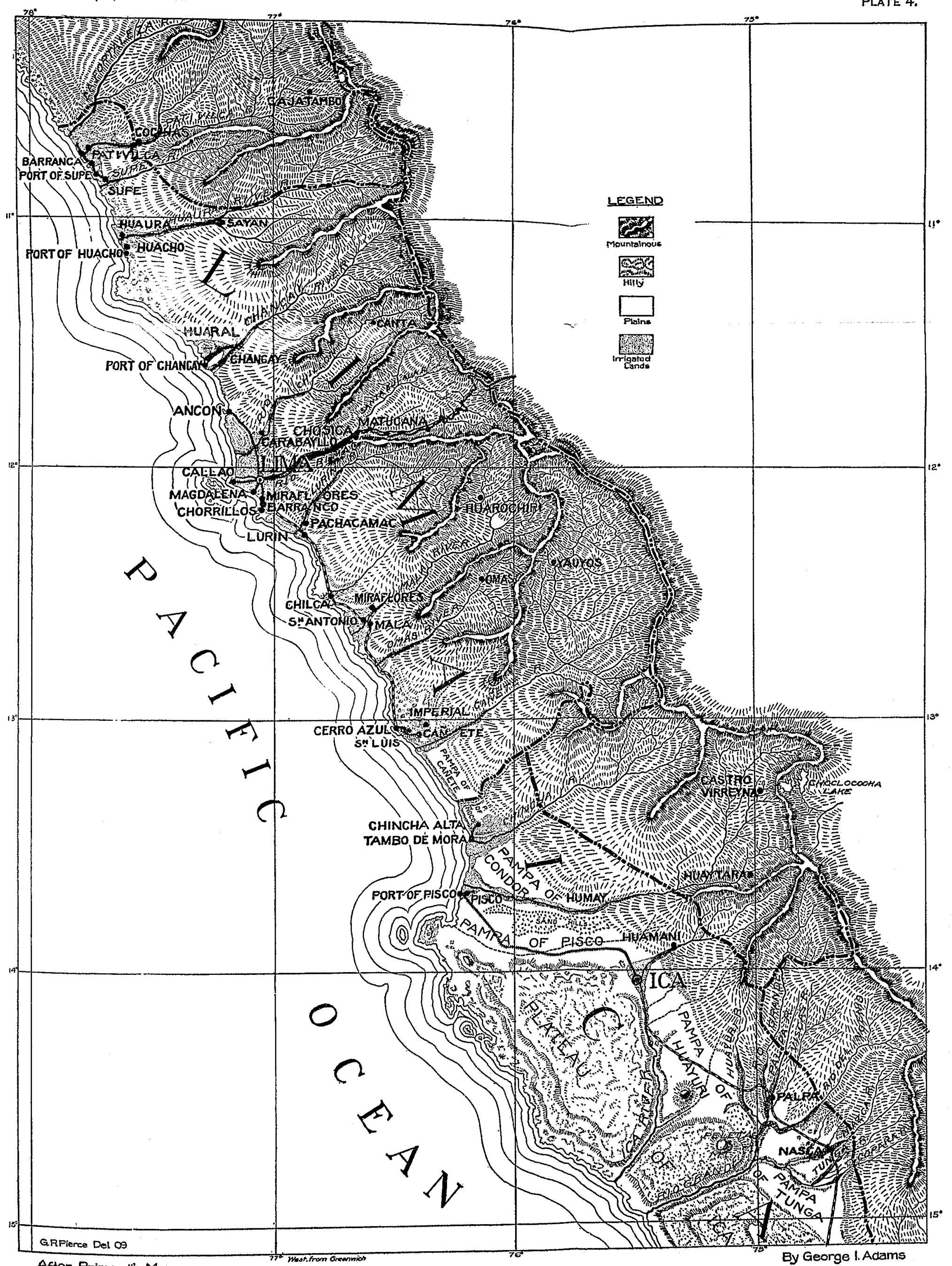

After Raimandís Map

hydrologic map of the South Central division of the Pacific slope of Peru. Departments of Lima and Ica.

pproximnte limit of annual rainfall half way between western Cordilleras and coast. 


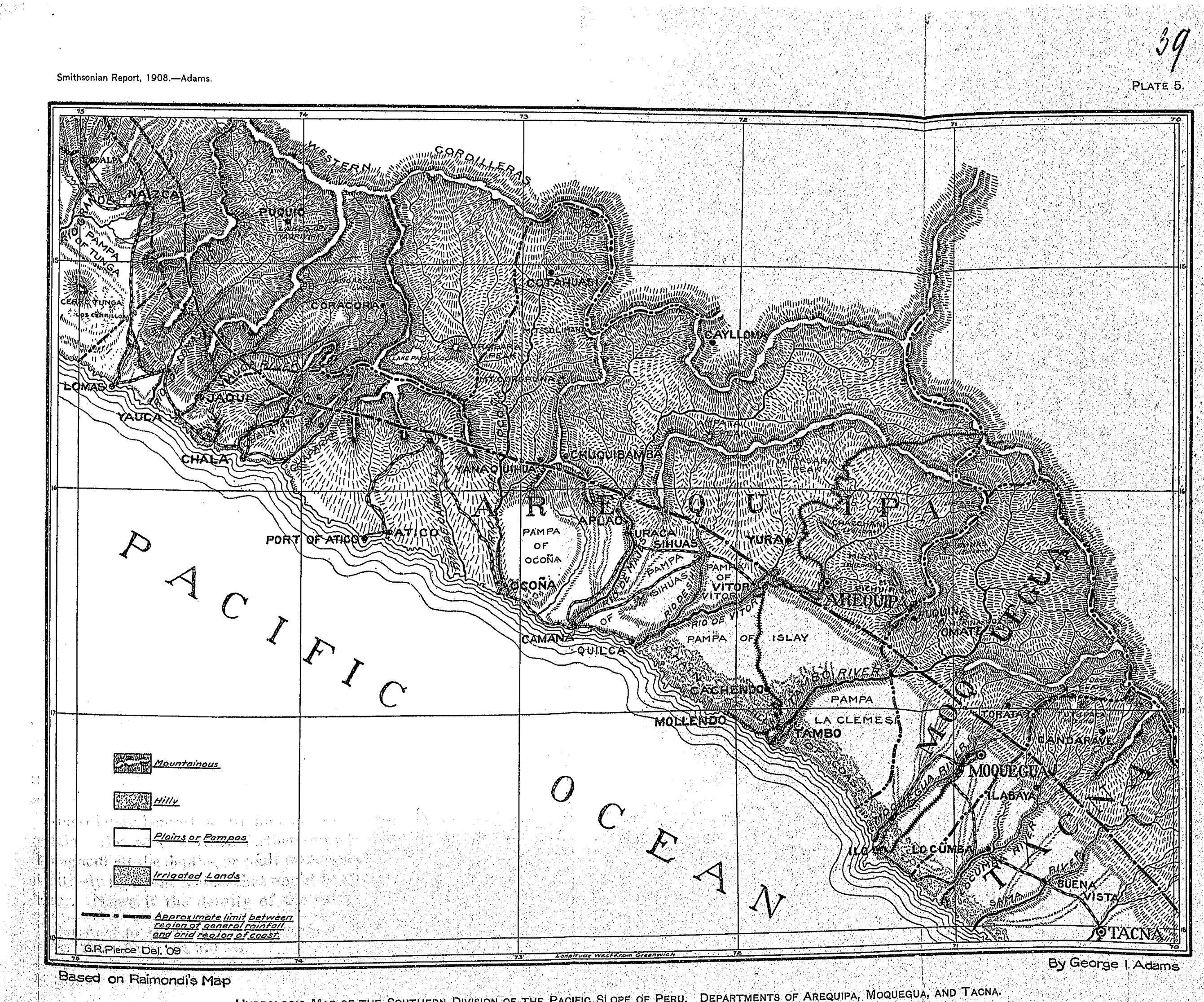

